\title{
Trophic importance of diatoms in an intertidal Zostera noltii seagrass bed: Evidence from stable isotope and fatty acid analyses
}

\author{
Benoit Lebreton $^{\mathrm{a}, 1, \star}$, Pierre Richard ${ }^{\mathrm{a}}$, Robert Galois ${ }^{\mathrm{a}}$, Gilles Radenac ${ }^{\mathrm{a}}$, Camille Pfléger $^{\mathrm{a}}$, Gaël Guillou $^{\mathrm{a}}$, \\ Françoise Mornet ${ }^{b}$ and Gérard F. Blanchard ${ }^{a}$
}

\footnotetext{
${ }^{a}$ Littoral Environnement et Sociétés (LIENSs), UMR 6250 CNRS-Université de La Rochelle, Institut du Littoral et de l'Environnement, 2 rue Olympe de Gouges, 17000 La Rochelle, France

${ }^{\mathrm{b}}$ Environnement Littoral Atlantique (ELA), UMS 3109 CNRS-IFREMER, Place Gaby Coll, BP 5, 17137 L'Houmeau, France

${ }^{1}$ Present address: Harte Research Institute for Gulf of Mexico Studies, Texas A\&M University Corpus Christi, 6300 Ocean Drive, Corpus Christi, TX 78412-5869, USA.
}

\author{
*: Corresponding author: Benoit Lebreton, Tel.: +33 (0) 5465076 41; fax: +33 (0) 5465076 63, \\ email address : benoit.lebreton@univ-Ir.fr
}

\begin{abstract}
:
A current predominant paradigm emphasizes the role of epiphytic algae for invertebrates in most seagrass food webs. However, in some intertidal Zostera noltii beds, epiphyte biomass is very low compared to microphytobenthos and seagrass biomasses. We assessed the role of microphytobenthos in a temperate intertidal $Z$. noltii bed by combining stable isotope and fatty acid (FA) analyses on primary producers, composite sources - suspended particulate organic matter (SPOM) and sediment surface organic matter (SSOM) - and the main macrofaunal consumers. $Z$. noltii showed high $\delta^{13} \mathrm{C}(-9.9 \%)$ and high 18:2(n-6) and 18:3(n-3) contents. Microphytobenthos was slightly more ${ }^{13} \mathrm{C}$-depleted $(-15.4 \%)$ and had high levels of diatom markers: 14:0, 16:1(n-7)c, 20:5(n3). Low mean $\delta^{13} \mathrm{C}(-22.0 \%)$ and large amounts of diatom and bacteria $(18: 1(n-7) \mathrm{c})$ markers indicated that SPOM was mainly composed of a mixture of fresh and decayed pelagic diatoms. Higher mean ${ }^{13} \mathrm{C}(-17.9 \%)$ and high amounts of diatom FAs were found in SSOM, showing that microphytobenthic diatoms dominate. Very low percentages of $18: 2(n-6)$ and 18:3(n-3) in consumers indicated a low contribution of $Z$. noltii material to their diets. Grazers, deposit and suspension-deposit feeders had ${ }^{13} \mathrm{C}$ close to microphytobenthos and high levels of diatom FAs, confirming that microphytobenthos represented the main part of their diet. Lower $\delta^{13} \mathrm{C}$ and higher amounts of flagellate FAs $-22: 6(n-3)$ and 16:4(n-3) - in suspension feeders indicated that their diet resulted from a mixture of SPOM and microphytobenthos. These results demonstrate that invertebrates do not consume high amounts of seagrass and highlight the main role of benthic diatoms in this intertidal seagrass bed.
\end{abstract}




\section{Research highlights}

Role of microphytobenthos was assessed in a temperate intertidal Z. noltii bed food web by combining stable isotope and fatty acid analyses. A low contribution of $Z$. noltii material was observed in consumer diets. Diet of suspension feeders resulted from a mixture of suspended particulate organic matter and microphytobenthos. Microphytobenthos represent the main part in the diet of grazers, deposit and suspension-deposit feeders. - We demonstrate that invertebrates do not consume high amounts of seagrass and highlight the main role of benthic diatoms in this intertidal seagrass bed.

Keywords : food web; intertidal seagrass bed; microphytobenthos; Zostera noltii; stable isotope ratio; fatty acid profiles; European Atlantic coast

Abbreviations: FA, Fatty acid; FAME, Fatty acid methyl ester; FIA, Flow injection analysis; LCFA, Long chain fatty acid; MTBE, Methyl tert-butyl ether; SPOM, Suspended particulate organic matter; SSOM, Sediment surface organic matter 


\section{Introduction}

Seagrass beds are widespread in shallow coastal waters (Green and Short, 2003), where they are considered to be one of the most productive ecosystems (Duarte and Chiscano, 1999). This high productivity is not due to angiosperm production alone, even though it can be very high (in average more than $1000 \mathrm{gC} . \mathrm{m}-2 . y e a r-1$ according to Duarte and Chiscano, 1999), since algae are known to contribute significantly to total system production (Daehnick et al., 1992; Moncreiff et al., 1992; Borowitzka et al., 2006). Epiphytic algae can thus represent up to $62 \%$ (Wear et al., 1999, but see Borowitzka et al., 2006 for a review) and microphytobenthic algae can represent up to $54 \%$ (Lebreton et al., 2009 and reference therein) of the seagrass bed production. Organic matter sources that support seagrass food webs are still debated and, depending on sites, different sources have been described as the main drivers of the seagrass food web (Mateo et al., 2006). The current predominant paradigm, based on the analysis of subtidal seagrass beds, asserts that diverse micro- or macroalgal epiphytes attached to seagrass leaves are the main food source for macrofaunal invertebrates (Kitting et al., 1984; Moncreiff and Sullivan, 2001; Borowitzka et al., 2006; Mateo et al., 2006; Jaschinski et al., 2008) because they can reach high biomass (Borowitzka et al., 2006) and may provide better quality nutrients compared to seagrasses (Cebrián, 1999).

However, in intertidal Zostera noltii beds, widespread along European Atlantic coasts (Green and Short, 2003), this paradigm might not hold because epiphyte biomass has been shown to be very low (between 0.001 and $0.20 \%$ of the leaf biomass according to Hootsmans et al., 1993; Philippart, 1995; Schanz et al., 2002; Lebreton et al., 2009) compared to the large amount of seagrass or microphytobenthos biomass, which is sometimes equal to leaf biomass (Asmus and Asmus, 1985; Guarini et al., 1998; Lebreton et al., 2009). Microphytobenthos plays an important role in most intertidal habitats, particularly in bare mudflats (Riera and Richard, 1996; Choy et al., 2008) but little is known about its trophic role in seagrass beds (Boschker et al., 2000; Moncreiff and Sullivan, 2001; Jaschinski et al., 2008).

Discriminating microphytobenthos and its potential importance in such ecosystems is technically challenging because of the high diversity and variability (qualitatively and quantitatively) of the different food sources. Seagrass ecosystems are fueled by numerous primary producers and composite food sources (e.g. SPOM, SSOM) which are themselves mixtures of primary producers and/or their degraded forms (Mateo et al., 2006). These primary producers and composite food sources both undergo seasonal changes in their characteristics which affect their quality and availability for consumers (Duarte, 1989; Borowitzka et al., 2006). Moreover, metabolic processes can affect fresh organic matter properties during its assimilation or degradation, complexifying trophodynamics understanding (Benner et al., 1987). Natural ratios of stable isotopes and FAs profiles of primary consumers are known to be generally close to those of their main food sources (Sargent and Whittle, 1981; Fry, 2006). Although natural ratios of stable isotopes have been shown to be useful to identify trophic relationships, they often lead to ambiguous conclusions in such complex systems because the values of sources frequently overlap and are highly variable (Fry et al., 1987), particularly for benthic producers. Moreover, stable isotopes do not allow a reliable discrimination of bacterial material, since bacteria have isotopic ratios close to their substrate (Abraham et al., 1998; Boschker et al., 2000) and because isolation of bacteria for stable isotope analyses are practically impossible. Thus, the analysis of food web functioning requires additional complementary information to better discriminate food sources. More recent ecological studies that use a combination of stable isotope ratios and FA profiles have demonstrated the usefulness of these two tracers to improve the understanding of 
complex trophic relationships (Kharlamenko et al., 2001; Nyssen et al., 2005; Jaschinski et al., 2008). In our case, FA profiles can improve discrimination between microphytobenthos and $Z$. noltii sources because they can be distinguished based on their specific FAs, particularly $(n-3)$ polyunsaturated FAs and saturated long chain FAs (Kharlamenko et al., 2001; Jaschinski et al., 2008). Moreover, FAs clearly discriminate bacteria due to the high specificity of prokaryotic FAs.

The present study was undertaken to determine the role of microphytobenthos in an intertidal seagrass bed in Marennes-Oléron Bay (France). Stable isotope ratios and FA profiles of major primary producers were characterized and the origin of composite food sources was determined. The fate of these resources was studied on six macrofaunal species, largely representative of the total trophic fluxes since they account for more than $90 \%$ of macrofaunal biomass (Lebreton, 2009). The comparison of stable isotope ratios and FA profiles in food sources and in dominant macrofaunal consumers allowed for the identification of the main trophic fluxes and highlighted the role of benthic diatoms.

\section{Materials and methods}

\subsection{Study area}

The study was carried out in a $Z$. noltii meadow in Marennes-Oléron Bay, a semienclosed system along the French Atlantic coast $\left(45^{\circ} 54^{\prime} \mathrm{N}, 1^{\circ} 12^{\prime} \mathrm{W}\right)$ (Fig. 1). This macrotidal bay (tidal range $0.9-6.5 \mathrm{~m}$ ), located between Oléron Island and the mainland, receives continental water mainly from the Charente River, which flows out into the eastern side of the bay. The studied seagrass bed is located on the western side of the bay, along Oléron Island, where the bay is more strongly influenced by offshore marine waters (Dechambenoy et al., 1977). The studied $Z$. noltii bed extends over $15 \mathrm{~km}$ along the shore and is $1.5 \mathrm{~km}$ wide in the upper part of the flat, limited in its lower part by extensive oyster farm structures (Guillaumont, 1991).

The sampling station in the seagrass bed was located at about $250 \mathrm{~m}$ seaward its upper limit (Fig. 1). Fluctuations in the biomass of the different benthic food sources ( $Z$. noltii and its detrital matter, epiphytes and microphytobenthos) and of macrofaunal consumers were studied previously in 2006 (Lebreton, 2009; Lebreton et al., 2009). The major feature of this seagrass bed is that epiphytes are exclusively composed of diatoms from the genus Cocconeis and have very low biomass, three orders of magnitude lower than that of microphytobenthos (Lebreton et al., 2009), dominated by a large diversity of small pennate diatoms (Bogaczewicz-Adamczak, unpublished data). The macrofaunal community is largely dominated by grazers, mainly represented by Hydrobia ulvae $(71 \%$ of the biomass) as in many other seagrass beds (Jacobs and Huisman, 1982; Asmus and Asmus, 1985; Schanz et al., 2002) and Littorina littorea (6\% of the biomass). Suspension feeders Tapes phillipinarum and Cerastoderma edule are much less abundant and account for about $13 \%$ of the biomass. Scrobicularia plana and Arenicola marina represent on average 7 and $0.4 \%$ of the biomass, respectively (Lebreton, 2009).

\subsection{Sample collection and preparation for isotope and FA analyses}

Food sources and consumers were sampled in winter and summer 2006 for stable isotopes analyses and in winter and summer 2007 for stable isotope and FA profile analyses. All food sources (except SPOM in 2006) were collected in the middle of each season and consumers at the end of each season to account for the dynamic nature of 
the marker signal integration within tissues of consumers. Numerous studies have shown that consumer isotope signature or FA composition reflects the average isotopic or FA composition of the diet assimilated over periods of weeks to months (Tieszen et al., 1983; Shin et al., 2008). A 1 month time lag between ingestion of sources and their integration in invertebrate consumers' tissues appeared as a good compromise taking into account the size of the macrofaunal species studied here but also possible variations of source isotopic compositions. In 2006, SPOM was biweekly sampled (3 to 5 replicates per sample) to study intraseasonal variations. Epiphytes were not sampled in winter due to the absence of $Z$. noltii leaves.

Above-ground (leaves) and below-ground (roots) parts of $Z$. noltii were rinsed with tap water to remove detrital fragments. Coarse detrital matter from $Z$. noltii was collected for stable isotope analysis by sieving sediment on a $500 \mu \mathrm{m}$ mesh sieve. Two types of detrital matter were collected by handpicking: fresh detrital matter, characterized by light brown colored pieces of rhizomes and roots, and degraded detrital matter, mostly composed of dark brown to black material. Samples were freeze-dried then ground to a fine and homogeneous powder using a ball mill. Samples were stored at $-20^{\circ} \mathrm{C}$ for stable isotope analysis and at $-80^{\circ} \mathrm{C}$ under a nitrogen atmosphere for FA analysis.

For SSOM analyses, surface sediment was sieved wet on a $315 \mu \mathrm{m}$ mesh sieve, freezedried, ground using a mortar and pestle, and stored in the same manner as $Z$. noltii samples.

SPOM from surface water was sampled at mid-tide. A volume of seawater from 50 to 60 $\mathrm{mL}$ for stable isotopes and from 16 to $20 \mathrm{~L}$ for FA analyses was pre-filtered on a $200 \mu \mathrm{m}$ mesh sieve to eliminate large zooplankton and detrital particles. Then water was filtered on precombusted Whatman GF/F glass fiber filters under moderate vacuum and stored in the same manner as other food sources.

The scraping methods generally used to collect epiphytes on seagrass leaves were not satisfactory owing to the very low biomass of epiphytes (Lebreton et al., 2009) and of the narrowness of $Z$. noltii leaves: from 0.5 to $2 \mathrm{~mm}$ width. The best separation method was found to be agitation (Cattaneo et al., 1995): leaves were first thoroughly rinsed with filtered seawater then vigorously shaken using a vortex mixer. The only epiphytes found on Z. noltii leaves in this seagrass bed were two species of epiphytic diatoms (Cocconeis scutellum and Cocconeis placentula) (Lebreton et al., 2009) so these diatoms were separated from organic and mineral detrital matter using a filtration method based on the narrow size spectrum of Cocconeis spp. diatoms (Round et al., 1990). The extracted solution was successively filtered on 48 and $10 \mu \mathrm{m}$ mesh nets, then concentrated on 5 $\mu \mathrm{m}$ mesh polycarbonate membranes (Nucleopore, Whatman) under moderate vacuum. Membranes were carefully washed in filtered seawater, and epiphyte samples were concentrated by successive centrifugations (10 min., $1000 \mathrm{~g}$ ), after checking the sample quality (state of cells, absence of detrital matter) under a microscope. Diatoms were then freeze-dried, homogenized and stored in the same manner as other food sources. Around $200 \mathrm{~g}$ of fresh leaves were necessary to obtain more than $50 \mathrm{mg}$ of dry material, which was the minimal total mass for isotope and FAs analyses.

In the studied seagrass bed, mats of epipelic diatoms were very rare at the sediment surface. Nevertheless, surficial sediment was scraped and microphytobenthos was extracted in the laboratory following Riera and Richard (1996) and Herlory et al. (2007). Extracted samples were checked under a microscope for purity (samples exclusively composed by microalgae), then centrifuged, freeze-dried and stored in the same manner as other food sources. 
Six dominant macrofaunal species (representing more than $90 \%$ of the total macrofaunal biomass) were sampled (Lebreton, 2009): two gastropod grazers (H. ulvae and Littorina littorea), two bivalve exclusive suspension feeders (C. edule and $T$. phillipinarum), one bivalve suspension-deposit feeder (Scrobicularia plana) and one annelid deposit feeder (Arenicola marina). These species were collected by sieving the sediment in the field and were kept alive for 36 hours in filtered seawater to allow gut content evacuation, before storage at $-20^{\circ} \mathrm{C}$ or $-80^{\circ} \mathrm{C}$ for stable isotope and FA analyses, respectively. Mollusks were removed from their shell, freeze-dried and ground using a ball mill. For stable isotope analyses, three entire individuals were analyzed (one small, one medium, one large) to be representative of the whole population, except for $H$. ulvae, which smallest individuals were pooled in groups of five individuals to obtain enough material. For FA analyses, 4 to 300 entire individuals per species, depending on their size, were pooled.

\subsection{Stable isotope ratio analyses}

When necessary, samples were acidified to remove carbonates: filters using $\mathrm{HCl}$ fumes, sediments using $1 \mathrm{~mol} . \mathrm{L}^{-1} \mathrm{HCl}$. Samples were then precisely weighed $( \pm 0.001 \mathrm{mg})$ in a tin capsule for stable isotope analysis and were analyzed using an isotope ratio mass spectrometer (Isoprime Micromass, UK) coupled to an elemental analyzer (EuroVector EA 3024, Italy). Isotope values are expressed in the $\delta$ unit notation as deviations from standards (Vienna Pee Dee Belemnite for $\delta^{13} \mathrm{C}$ and atmospheric $\mathrm{N}_{2}$ for $\delta^{15} \mathrm{~N}$ ) following the formula $\delta^{13} \mathrm{C}$ or $\delta^{15} \mathrm{~N}=\left[\left(R_{\text {sample/ }} R_{\text {standard }}\right)-1\right]^{\star} 10^{3}$, where $R$ is ${ }^{13} \mathrm{C} /{ }^{12} \mathrm{C}$ or ${ }^{15} \mathrm{~N} /{ }^{14} \mathrm{~N}$. The analytical precision of the measurements was $<0.15 \%$ and $<0.2 \%$ for carbon and nitrogen, respectively.

\subsection{Lipid extraction and FA analysis}

Lipids were extracted from freeze-dried powders by a procedure modified from Folch et al. (1957). Samples were extracted 3 times with chloroform:methanol (1:2, 2:1 and 4:1, $\mathrm{v} / \mathrm{v})$. A volume of $1 \% \mathrm{NaCl}$ solution was added and the mixture separated into 2 phases. The lower layer containing lipids was collected and water removed by addition of dry sodium sulfate. These extracts were stored in the dark at $-26^{\circ} \mathrm{C}$. Total lipids were quantified by flow injection analysis (FIA) using an HPLC system (Agilent Technologies) without column, coupled to an evaporative light-scattering detector (Polymer Laboratories).

Lipids were transmethylated by acid catalysis at $80^{\circ} \mathrm{C}$ for $2 \mathrm{~h}$ in $\mathrm{H}_{2} \mathrm{SO}_{4}$-methanol $(4 \%$, $\mathrm{w} / \mathrm{v})$ reagent (Christie, 1984) with addition of toluene $(10 \%, \mathrm{v} / \mathrm{v})$, to yield FA methyl esters (FAMEs). An internal standard (21:0) was added before transmethylation for the quantification of FAMEs. Water was added and FAMEs were extracted twice with a mixture of hexane:methyl tert-butyl ether (MTBE) 80:20 (v/v).

FAME purification was done in two steps. First, a Flash-LC was carried out on the HPLC fitted with a semi-preparative column (100 mm length * $10 \mathrm{~mm}$ ID) filled with a Puriflash Si-CN $60 \mu \mathrm{m}$ phase (Interchim, France). A polarity gradient from 0.010 to 0.614 , based on hexane:dichloromethane:methanol mixtures, allowed the separation of semi-polar compounds from non-polar compounds including FAMEs. Second, the HPLC was fitted with a semi-preparative HPLC column (250 mm length * $10 \mathrm{~mm}$ ID) filled with an Uptisphere Si-CN $5 \mu \mathrm{m}$ phase (Interchim, France). A polarity gradient from 0.010 to 0.121 , based on hexane:MTBE:acetone mixtures separated hydrocarbons and wax or sterol esters from FAMEs. The collected FAMEs were quantified by FIA as for total lipids before separating them by gas chromatography. 
FA compositions were determined using a gas chromatograph (GC-6890N, Agilent Technologies) equipped with an automatic sampler and a J\&W DB-23 capillary column $(60 \mathrm{~m} \times 0.25 \mathrm{~mm}$ ID $\times 0.25 \mu \mathrm{m}$ film). Operating conditions were as follows: injector in split mode $(1 / 20$ to $1 / 40)$ at $240^{\circ} \mathrm{C}, 1 \mu \mathrm{L}$ injected; detector FID at $260^{\circ} \mathrm{C}$; carrier gas hydrogen in constant flow mode at an average linear velocity of $30 \mathrm{~cm} . \mathrm{sec}^{-1}$; linear temperature gradient from 100 to $240^{\circ} \mathrm{C}$ at $1^{\circ} \mathrm{C} \cdot \mathrm{min}^{-1}$.

FAME identification was performed by comparing relative retention times with those of known standard mixtures: 37-FAME Mix, 26-BAME Mix, PUFA-2 and PUFA-3 (Supelco, Sigma Aldrich Chemicals). Equivalent chain lengths (Christie, 1988) were used as an aid in peak localization and identification. Each FAME area was corrected from the corresponding FID response factor (Bannon et al., 1986) and from the difference in weight between the FAME and its corresponding free FA.

\subsection{Data and statistical analyses}

Isotope ratios of consumers and food sources were compared considering a trophic enrichment of $0.8 \%$ for $\delta^{13} \mathrm{C}$ and of $2.5 \%$ for $\delta^{15} \mathrm{~N}$ (Vander Zanden and Rasmussen, 2001). FA results are expressed as the percent of each FA relative to the sum of all identified FAs. Only FAs with proportions higher than $0.004 \%$ were used in the data analysis. FA biomarkers were identified from published literature and, for trophic relation analysis, were associated with single groups of FA primary producer markers (vascular plants, diatoms, flagellates or bacteria) or considered as ubiquitous marker (Table 1). In order to enhance the discrimination between primary producers ( $Z$. noltii, microphytobenthos, epiphytes), composite food sources (SPOM, SSOM) and consumers, $\delta^{13} \mathrm{C}$ values were plotted versus values from each of these four groups of FA primary producer markers, as suggested by Nyssen et al. (2005).

Due to small sample size (replicate number almost always $<10$ ) and non-independence of data within series, non-parametric procedures were used to achieve more robust statistics. Kruskal-Wallis tests were applied on isotopic data in order to compare the different food sources and consumers, and to test seasonal isotopic variations. These tests were followed by multiple comparisons of means using the pgirmess $\mathrm{R}$ package. Wilcoxon signed-ranks tests were used to identify differences in FA compositions of food sources and consumers among seasons. Hierarchical clustering analyses (Ward's method, Euclidean distance) were used to compare sources and consumers within seasons using the pvclust $\mathrm{R}$ package. Using this package, $\mathrm{p}$-values were computed based on multiscale bootstrap resampling to determine the level of significance of identified clusters.

\section{Results}

\subsection{Stable isotope composition of food sources}

Mean $\delta^{13} \mathrm{C}$ of food sources ranged from -23.8 (SPOM, winter 2006) to $-9.3 \%$ (roots, summer 2006) (Fig. 2A). Except for SPOM, temporal variations were low and, when statistical differences were observed, they do not allow detecting any seasonal pattern (Table 2). On an annual basis, some food sources exhibited large differences in their $\delta^{13} \mathrm{C}$ values (Kruskal-Wallis test, $\mathrm{p}<0.001$, table 2). SPOM was always the most ${ }^{13} \mathrm{C}$ depleted except in summer 2007 (annual mean: -22.0\%) and was significantly different from Z. noltii material all year long (Table 2). In 2006, intraseasonal variations of SPOM 
$\delta^{13} \mathrm{C}$ were observed in winter, with lower $\delta^{13} \mathrm{C}$ at the end, but not in summer (Table 3). SPOM was much more ${ }^{13} \mathrm{C}$-enriched in summer 2007 than in all other seasons, with values close to those of microphytobenthos. Alive or fresh detrital organic matter originating from $Z$. noltii showed the highest $\delta^{13} \mathrm{C}$ values (from -10.4 to $-9.7 \%$ ) but degraded detrital matter was slightly, but not significantly, more depleted in ${ }^{13} \mathrm{C}$ (annual mean $=-12.8 \%$ ). SSOM (annual mean $=-17.9 \%$ ) was significantly more depleted than $Z$. noltii leaves and roots. Microphytobenthos $\delta^{13} \mathrm{C}$ values (annual mean $=-15.4 \%$ ) were intermediate between those of SSOM and $Z$. noltii material and the $\delta^{13} \mathrm{C}$ value of epiphytic diatoms $(-12.8 \%)$ was close to those of $Z$. noltii material.

Mean $\delta^{15} \mathrm{~N}$ of food sources ranged from 4.9 (leaves, winter 2006) to 10.5\% (roots, summer 2007) and $\delta^{15} \mathrm{~N}$ values of $Z$. noltii material showed large standard deviations relative to $\delta^{13} \mathrm{C}$ (Table 2). No seasonal pattern was observed even if some statistical differences could be observed between seasons (Table 2). On an annual basis, SSOM was more depleted in ${ }^{15} \mathrm{~N}$ than $Z$. noltii material (Kruskal-Wallis test, $p=0.012$ ).

\subsection{Stable isotope composition of consumers}

Mean $\delta^{13} \mathrm{C}$ values of consumers ranged from -16.9 (C. edule, winter 2007) to -8.8\%o ( $L$. littorea, summer 2007) (Fig. 2B). On an annual basis, grazers ( $H$. ulvae and $L$. littorea) were the most ${ }^{13} \mathrm{C}$-enriched $\left(\delta^{13} \mathrm{C}\right.$ ranging from -8.8 to $-11.8 \%$ ). Grazers $\delta^{13} \mathrm{C}$ were significantly different from these of suspension feeders ( $C$. edule and $T$. phillipinarum), which were the most depleted organisms $\left(\delta^{13} \mathrm{C}\right.$ ranging from -16.9 to $\left.-13.9 \%\right)$. $\delta^{13} \mathrm{C}$ values of $L$. littorea were also higher than those of $A$. marina (deposit feeder) (KruskalWallis test, $p<0.001$ ). S. plana and $A$. marina showed $\delta^{13} \mathrm{C}$ that were intermediate between suspension feeders and grazers: from -13.2 to $-14.3 \%$ and from -12.6 to -14.0 , respectively. All consumers except $A$. marina exhibited higher $\delta^{13} \mathrm{C}$ values in summer than in winter, but no significant differences were observed. $L$. littorea and $C$. edule $\delta^{13} C$ presented large standard deviations (Fig. 2B, table 2).

Mean $\delta^{15} \mathrm{~N}$ values ranged from 7.6 (T. philippinarum, summer 2007) to $12.8 \%$ (S. plana, winter 2007) and, on an annual basis, A. marina presented $\delta^{15} \mathrm{~N}$ values higher than those of $H$. ulvae, T. phillipinarum and $C$. edule (Kruskal-Wallis test, $p<0.001$ ). No clear seasonal pattern was observed for ${ }^{15} \mathrm{~N}$ values (Table 2 ).

\subsection{FA profiles of food sources}

Eighty-one FAs were identified and used for food source data analysis. Within seasons, FA profiles of $Z$. noltii material were clearly distinguished from microphytobenthos, epiphytes, SSOM and SPOM (Fig.3).

Roots and leaves contained large quantities of two vascular plant FA markers in contrasting proportions $(18: 2(n-6)$ mean: leaves $=14.5 \%$, roots $=35.3 \% ; 18: 3(n-3)$ mean: leaves $=47.7 \%$, roots $=16.0 \%)$. $Z$. noltii was also enriched in some saturated long-chain FAs (LCFAs) such as 24:0 in roots (mean $=5.4 \%$ ) and leaves (mean $=1.4 \%$ ), as well as 26:0 (mean $=2.4 \%)$ and 28:0 (mean $=1.3 \%$ ) in roots. Vascular plant FA markers thus represented, on an annual basis, $62.5 \%$ and $65.4 \%$ of total FAs in roots and leaves, respectively (Fig. 3). FAs profiles of $Z$. noltii roots and leaves were significantly different between winter and summer (Wilcoxon tests, leaves: $p<0.0001$, roots: $p=0.020$ ), with higher proportions of ubiquitous FAs in summer.

Microphytobenthos presented high proportions of diatom markers (mean $=34.8 \%$ ), including large quantities of 20:5 $(n-3)$ (mean $=17.9 \%), 16: 1(n-7)$ c (mean $=5.8 \%)$ and 
14:0 (mean $=5.2 \%$ ). Concentrations of typical flagellate FAs were also relatively high $($ mean $=6.9 \%)$, particularly those of 22:6(n-3) (mean $=1.9 \%)$ and 18:4 $(n-3)$ (mean $=$ 1.1\%) (Fig. 3). FAs profiles were different between winter and summer $(p=0.020)$ with a higher proportion of diatom FAs in winter.

FA composition in epiphytes was also characterized by a large proportion of diatom markers (21.2\%), including 16:1(n-7)c (11.4\%), 20:5(n-3) (3.3\%) and 14:0 (3.9\%). Percentages of flagellate FA markers were lower in epiphytes (3.7\%) than in microphytobenthos (Fig. 3).

SSOM FAs profiles followed those of microphytobenthos at each season and were thus different between winter and summer $(p<0.0001)$. SSOM contained large proportions of diatom FA markers, with the highest percentage in winter (56.6\%) compared to summer (33.6\%). In contrast, proportions of vascular plant and bacterial FAs were higher in summer (vascular plants: summer $=6.2 \%$, winter $=2.3 \%$; bacteria: summer $=17.3 \%$, winter $=6.2 \%)$.

SPOM profiles were dominated by ubiquitous FAs: 16:0, 18:0 and 18:1(n-9)c, representing on average $37.0 \%$ of the total (Fig. 3). High proportions of $16: 1(n-7) \mathrm{c}$ (mean $=7.7 \%), 20: 5(n-3)($ mean $=4.8 \%)$ and 14:0 (mean $=6.6 \%)$ FAs, all diatom markers, and large quantities of bacterial FAs (mean $=15.9 \%$ ), including $5.3 \%$ of $18: 1(n-7)$ c, were also observed. Flagellate FA markers were rather low (5.3\%). No difference of profile was observed between summer and winter $(p=0.430)$.

\subsection{FA profiles of consumers}

Seventy-height FAs were identified and used for consumer data analysis. Hierarchical clustering analyses allow discriminating 3 groups of consumers: 1 . deposit feeders $(A$. marina), 2. suspension feeders (T. phillipinarum and $C$. edule) and 3 . grazers and suspension-deposit feeder (H. ulvae, L. littorea and S. plana) (Fig. 4). Among seasons, FA profiles differed only for $C$. edule and $S$. plana (Wilcoxon-tests, $A$. marina: $p=0.323$, C. edule: $p=0.003, H$. ulvae: $p=0.512$, L. littorea: $p=0.482$, S. plana: $p=0.045, T$. philippinarum: $\mathrm{p}=0.151$ ).

Both species of grazers were highly enriched in diatom markers (mean $=22.3 \%$ ), including on average $15.1 \%$ of $20: 5(n-3)$. Large proportions of flagellate markers were also observed (mean $=11.8 \%)$. Bacterial and vascular plant markers had low proportions, with on average 7.0 and $4.5 \%$ of total FAs, respectively.

S. plana FA composition was dominated by diatom markers (mean $=19.0 \%$ ), particularly 20:5( $n-3)$. Flagellate markers were the second most frequent marker (mean $=13.1 \%$ ), followed by bacterial markers (mean $=7.1 \%$ ) and vascular plant markers (mean $=1.8 \%$ ). Suspension feeders FA profiles were dominated by flagellate compounds, while percentages of diatom FAs were rather low (mean $=11.8 \%$ ). Bacterial FA percentages were higher than in grazers and suspension-deposit feeders with on average $10.2 \%$ of total FAs, and the proportion of vascular FAs was very low, with percentages less than $2.0 \%$.

A. marina had a characteristic FA profile in which bacterial FAs prevailed (mean $=$ $23.9 \%$ ), particularly the $18: 1(n-7)$ c. Proportions of diatom markers (mean $=19.5 \%$ ) were also high contrary to those of flagellate markers (mean $=10.0 \%)$. A. marina exhibited the lowest percentage of vascular plant markers (Fig. 4). 


\subsection{Two-dimensional analysis on food sources and consumers using $\delta^{13} \mathrm{C}$ and FA profiles}

Except for SPOM in summer $2007, \delta^{13} \mathrm{C}$ ratios discriminate relatively well among SPOM, SSOM, microphytobenthos and a fourth group composed of epiphytes and $Z$. noltii material. A great difference in FA composition occurred between $Z$. noltii material and all other food sources, including epiphytes, because $Z$. noltii has high quantities of vascular plant FAs while proportions of these FAs in other sources are very low (Fig. 5A). In contrast, percentages of diatom marker FAs in every food sources were relatively high, except for Z. noltii material. Composite food sources (SPOM and SSOM) had also high proportions of diatom FAs, with the highest proportion in SSOM in winter 2007 (Fig. 5B). On all plots, SPOM and microphytobenthos samples from summer 2007 presented very similar composition. Relatively low percentages of flagellate and bacterial FAs were observed (Fig. 5C and 5D).

The low proportions of vascular plant FA markers in all consumers made it difficult to differentiate any particular consumer from the others (Fig. 6A). The highest proportion of vascular plant FA markers was observed in grazer tissues, particularly $L$. littorea. All consumers presented high proportions of diatom markers, except suspension feeders which were also slightly depleted in ${ }^{13} \mathrm{C}$ (Fig. 6B). Suspension feeders were relatively enriched in flagellate markers (Fig. 6C) whereas other consumers were depleted. $A$ marina was very different from other species due to its enrichment in bacterial FAs.

\section{Discussion}

\subsection{Characterization of primary producers}

Few isotope composition data of the microphytobenthos or epiphytic diatoms are available, probably due to technical difficulties in sampling. In this seagrass bed, isotope compositions of epiphytic diatoms are in the same range than those of Carlier et al. (2009). For microphytobenthos, values measured in the present study are well within the range of previous observations from other seagrass beds: from -18 to $-11.5 \%$ (Dauby, 1995; Leduc et al., 2006; Kharlamenko et al., 2008) and from bare mudflats in MarennesOléron Bay (Riera and Richard, 1996; Malet et al., 2008). $\delta^{13} \mathrm{C}$ values of $Z$. noltii roots, leaves and fresh detrital matter fractions were also similar to the values found in the literature for the same species (Boschker et al., 2000; Schaal et al., 2008).

Z. noltii roots and leaves, microphytobenthos and epiphytic diatoms are much better characterized by their $\delta^{13} \mathrm{C}$ values and FA profiles than by their $\delta^{15} \mathrm{~N}$ values that largely overlap. However, $\delta^{13} \mathrm{C}$ of $Z$. noltii material are sometimes close to those of epiphytes or microphytobenthos, particularly detrital fractions of Zostera, because phanerogam degradation leads to $a{ }^{13} \mathrm{C}$-depletion likely due to higher levels of lignin which is ${ }^{13} \mathrm{C}$ depleted (Benner et al., 1987). Nevertheless, alive or detrital $Z$. noltii material can be well distinguished from epiphytes and microphytobenthos by their FA profiles. Epiphytic diatoms and microphytobenthos present in fact large quantities of typical diatom FAs such as 16:1(n-7)c, 14:0 and 20:5(n-3) (Viso and Marty, 1993; Dunstan et al., 1994; Bergé et al., 1995; Kharlamenko et al., 2008) and a very low proportion of FAs considered as markers of seagrass species. On the contrary, leaf and root FA profiles were typical of seagrass species with high levels of 18:2(n-6), 18:3(n-3) (Kharlamenko et 
al., 2001; Jaschinski et al., 2008 ) and of some LCFAs, particularly 24:0 in roots (Nichols et al., 1982; Khotimchenko, 1993; Viso et al., 1993).

The decaying process probably do not affect the vascular plant FAs in the same way: the LCFAs are very resistant to degradation (Nichols et al., 1982; Volkman et al., 1998) and can help identify decaying $Z$. noltii matter, especially in sediment. In contrast, 18:2(n-6) and 18:3(n-3) FAs are labile and degrade quickly (Nichols et al., 1982; Kharlamenko et al., 2001); they are therefore good markers of fresh $Z$. noltii material. These FA properties can consequently be used to characterize the presence of different decay stages during data analysis of composite food sources and consumers.

Epiphytic and microphytobenthic diatoms could probably be distinguished each other, due to their contrasting proportions of $16: 1(n-7) c$ and of $20: 5(n-3)$.

\subsection{Discrimination and composition of composite food sources}

The relative stability of stable isotope signatures and FA profiles of the primary producers throughout the year facilitated source identification using a dual-tracer approach. Nevertheless, some of them, such as Z. noltii (Auby and Labourg, 1996; Lebreton et al., 2009) or phytoplankton (Héral et al., 1987; Galois et al., 1996), exhibit large seasonal variations of their biomass, that can potentially affect the isotopic and FA composition of SPOM and SSOM.

Except in summer 2007, SPOM $\delta^{13} \mathrm{C}$ were very similar to previous measurements in the same area (Malet et al., 2008). These signatures encompasses the full range of $\delta^{13} \mathrm{C}$ between oceanic (-19.5 to $-21.8 \%$ ) and estuarine SPOM values (-22.6 to $-24.4 \%$ ) observed by Riera and Richard (1997) and classically encountered on an estuary-ocean continuum. This indicates that SPOM was composed by a mixture of material from both origins. Intraseasonal variation of $\delta^{13} \mathrm{C}$ in winter is thus probably related with the more variable hydrodynamic conditions (Charente River floods, storms...). FA profiles indicate that SPOM was composed by a mixture of fresh and decaying diatoms (Galois et al., 1996) associated with bacteria, whereas flagellates remained low. There are thus relatively high levels of $20: 5(n-3)$ and $16: 1(n-7)$ c, which are markers of living diatoms (Viso and Marty, 1993; Dunstan et al., 1994; Bergé et al., 1995), of 14:0, which presents a lower degradation rate than 16:1(n-7)c (Canuel and Martens, 1996), and of bacterial FAs (18:1(n-7)c). Even if 18:1(n-7)c has mainly a bacterial origin (Sargent et al., 1987; Volkman et al., 1998), it may also be present in different microalgae (Nichols et al., 1984; Volkman et al., 1989), suggesting that other groups than diatoms constitute also the phytoplanktonic assemblage. In summer 2007, there is evidence for high levels of resuspended microphytobenthos in SPOM samples because SPOM FA profile and $\delta^{13} \mathrm{C}$ were very similar to those of microphytobenthos. This observation highlights the importance of high frequency samplings for a good monitoring of SPOM composition.

SSOM $\delta^{13} \mathrm{C}$ values, intermediate between those of SPOM and those of benthic sources (i. e. Zostera material, microphytobenthos), showed that SPOM contributes significantly in SSOM composition. In seagrass beds, SPOM sedimentation may thus be enhanced because the seagrass canopy greatly weakens the hydrodynamism (Koch et al., 2006). SSOM FAs profiles, with high levels of diatom FAs and low levels of flagellate FA markers, demonstrate that SSOM was composed by a dominance of diatoms. This diatom material was present as living or fresh detrital matter since diatom FA markers are quickly degraded (Canuel and Martens, 1996). FA profiles of SSOM, which followed marked summer/winter difference of microphytobenthos FA profiles, confirmed that microphytobenthos largely contributes to SSOM composition. SSOM was thus mainly 
constituted by microphytobenthic diatoms, with a significant contribution of sedimented phytoplankton (Kharlamenko et al., 2008). Microphytobenthic diatoms thus can be available to deposit feeders and grazers but also to suspension feeders when resuspended in the water column.

These observations ruled out a possible contribution of $Z$. noltii organic matter or terrestrial organic matter (Copeman et al,. 2009) in SSOM since vascular plant FAs represented only a low percentage: 2.6 to $6.4 \%$ of the total, even when accounting for degradation-resistant LCFAs. This low contribution was unexpected considering the large amount of large $Z$. noltii organic matter in the sediment (Lebreton et al., 2009), that is probably deeply buried and thus locally much less available to consumers. This low contribution of seagrass organic matter and the dominance of diatom in SSOM composition has already been demonstrated at the same site (Vouvé, 2000) and in other seagrass beds (Boschker et al., 2000; Volkman et al., 2008).

\subsection{Limited use of seagrass material by macrofaunal consumers}

$\delta^{13} \mathrm{C}$ values of deposit feeders, suspension-deposit feeders and grazers are in the range of those of $Z$. noltii fresh or degraded material. Thus, considering an isotopic enrichment from food to consumers of $0.8 \%$ (Vander Zanden and Rasmussen, 2001), Z. noltii material could appear as a potential food resource for these consumers and particularly for grazers when fresh. However, the very low percentages of vascular plant FAs in these consumers-with sum less than $6 \%$-indicate that the contribution of fresh Z. noltii material was very low in their diets. Moreover, the low percentages of bacterial FAs and of LCFAs suggest also that degraded seagrass matter was not utilized via bacteria mediation. Even if the biomass of $Z$. noltii highly increased in summer, higher $\delta^{13} \mathrm{C}$ values observed for grazers at that period are probably not related with a higher consumption of seagrass material since grazer FA profiles showed no increase of vascular plant and bacteria markers. This absence of temporal variation highlights the limited utilization of seagrass material by grazers. Nevertheless, grazers had the highest $\delta^{13} \mathrm{C}$ values and the highest percentages of vascular plant FAs, demonstrating that these consumers are the most influenced by seagrass sources among all studied. These observations highlight the importance of trophic marker combination for complex food web analysis. In this case, a single stable isotope analysis would have been limited for a clear understanding of ecosystem trophodynamics.

A number of previous studies has emphasized the importance of fresh seagrass as the main food source for invertebrates (Valentine et al., 2000; Leduc et al., 2006; Schaal et al., 2008) but many others have demonstrated that this material is not consumed by most consumers (Kitting et al., 1984; Moncreiff and Sullivan, 2001; Borowitzka et al., 2006; Mateo et al., 2006; Jaschinski et al., 2008), and our observations confirmed this last hypothesis. This low utilization by invertebrate consumers can be explained by low nutritional quality of seagrass material that is poorly assimilated, has a low nitrogen content (Cebrián, 1999), high levels of lignin and tannins and can synthesize phenols, which consumers generally avoid (Harrison, 1982). Moreover, even though large amounts of $Z$. noltii detrital matter are stored in the sediment (Lebreton et al., 2009), this material is relatively unavailable for consumers because it is trapped in deep sediment layers, such as previously demonstrated in SSOM composition analyses.

\subsection{Influence of phytoplanktonic material}

Large amounts of flagellate FAs in suspension feeder profiles, particularly 22:6(n-3) and $16: 4(n-3)$, confirmed the influence of SPOM in their diet, as shown in other seagrass 
meadows (Kharlamenko et al., 2001; Jaschinski et al., 2008). Abundances of flagellates can be high in the water column (Fenchel, 1988; Galois et al., 1996) and are generally very low in sediment (Moorthi and Berninger, 2006; Pascal et al., 2009), suggesting that flagellates come from phytoplankton. In our SPOM samples, low percentages of flagellate FAs were observed, that may be linked to either the scarcity of flagellate cells compared with those of diatoms or bacteria, or to sampling carried out between the short successions of flagellate blooms observed in Marennes-Oléron Bay (Héral et al., 1987). It is worth noting that the stable isotope ratios and FA profiles of suspension feeders were not affected by the strong temporal variation in the quality and quantity of SPOM (Héral et al., 1987; Galois et al., 1996), probably due to the consumption of microphytobenthos resuspended by waves and tidal currents, which stabilizes consumer tissue compositions.

\subsection{Importance of diatoms in the seagrass food web}

Considering trophic enrichment, $\delta^{13} \mathrm{C}$ values of suspension-deposit feeders, deposit feeders and suspension feeders suggested that these consumers utilize microphytobenthos and SSOM as main food sources. We previously demonstrated that SSOM originates mostly from microphytobenthic diatoms (see section 4.2), reinforcing the role of this resource in these consumer diets. FA profiles showed a large influence of diatoms in diets of grazers, suspension-deposit feeders and deposit feeders. The combination of trophic markers for this study allows thus to determine that diatoms constitute the main part of the diet of all studied consumers, whichever their feeding types.

The high proportions of diatom markers in S. plana profiles and the $\delta^{13} \mathrm{C}$ close to microphytobenthos showed that this suspension-deposit feeder feeds mainly as a deposit feeder all year long on this area. Diatom FA percentages, particularly of 20:5( $n$ 3), are higher than those observed by Kharlamenko et al. (2001) in another typical suspension-deposit feeder (Macoma incongrua) from the Novgorodskaya Bight, where microphytobenthos biomass is considered to be very low. On the contrary, high microphytobenthos biomass was observed all year long in the Marennes-Oléron seagrass bed, explaining this higher contribution.

$\delta^{13} \mathrm{C}$ values and high FA percentages of diatom markers also demonstrated the high influence of microphytobenthos in $A$. marina diet. Nevertheless, large amounts of bacterial FAs and relatively higher $\delta^{15} \mathrm{~N}$ clearly discriminated it from other consumers. This deposit feeder generally has large amounts of bacteria in its digestive tract, which is considered as a form of gardening (Grossmann and Reichardt, 1991). A. marina has probably a diet based on these bacteria, which themselves use likely microphytobenthos as a substrate. Relatively higher $\delta^{15} \mathrm{~N}$ observed on $A$. marina are thus possibly related with this bacterial activity, known to increase ${ }^{15} \mathrm{~N}$ concentration due to isotopic fractionation (Dijkstra et al., 2008).

Diet of suspension feeders ( $T$. phillipinarum, $C$. edule) is also influenced by microphytobenthic diatoms, which are probably resuspended in the water column at high tide. Tides and waves make microphytobenthos available to suspension feeders, such as previously described on the east side of the Marennes-Oléron Bay, where epipelic diatoms contributed to the main part of suspension feeders' diets (Riera and Richard, 1996). Nevertheless the relatively low proportions of diatom markers in FA profiles indicated that diatoms have a lower influence on these consumer diets compared to others. The large standard deviations observed on $C$. edule $\delta^{13} \mathrm{C}$ were due to the wide 
size range of individuals analyzed, since in this bay a clear change in cocckle diet with age has been observed (Kang et al., 1999).

Considering that seagrass material represented a small part of grazer diets (see section 4.3), $\delta^{13} \mathrm{C}$ indicated that they were probably mostly based on microphytobenthic or epiphytic diatoms. The high percentages of diatom FAs confirmed that diatoms constitute the main part of grazers' diets and the balance between the high proportions of 20:5(n-3) and the low percentages of $16: 1(n-7) c$ suggests that diatoms have mainly a microphytobenthic origin.

\subsection{Epiphytic vs. microphytobenthic diatoms}

Some arguments are in favour of a higher role of microphytobenthos rather than epiphytes. Firstly, epiphytes are almost absent in winter due to the lack of seagrass leaves whereas microphytobenthos biomass is constant throughout the year (Lebreton et al., 2009). An exclusive or a large utilization of epiphytes by grazers in summer would lead to a large variation of $\delta^{13} \mathrm{C}$ between this season and winter, when epiphytes are absent, and our observations showed only a moderate enrichment of $\delta^{13} \mathrm{C}$. Moreover, proportions of 20:5(n-3) (high in microphytobenthos) and of 16:1(n-7)c (high in epiphytes) remain constant among seasons for these grazers, with high proportions of 20:5(n-3). Even if epiphytes are probably used by grazers as a food resource in summer, this suggests that epiphytes have a minor role in food fluxes in comparison with microphytobenthos.

Secondly, in the studied seagrass bed, the only epiphytes species found on Zostera leaves are Cocconeis diatoms which biomass are three orders of magnitude lower than microphytobenthos biomass (Lebreton et al., 2009). Considering that the productivity of epiphytic and microphytobenthic diatoms are relatively close (see Coleman and Burkholder (1995), Raniello et al. (2007), Lebreton (2009) for epiphytes and Maclntyre et al. (1996), Guarini et al. (2000) for microphytobenthos), productions of these sources are directly related to their biomass and should be also in a large disproportion. A rough calculation, based on the highest exponential growth rates found in literature for Cocconeis culture $\left(1.03 \mathrm{~d}^{-1}\right.$ ) (Raniello et al., 2007) and the highest biomass observed on

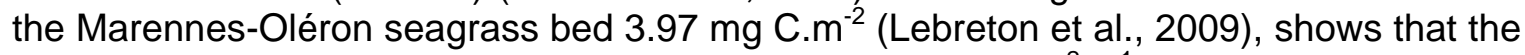
potential production of epiphytic diatoms is around $4 \mathrm{mg} \mathrm{C} \cdot \mathrm{m}^{-2} \cdot \mathrm{d}^{-1}$, while the ingestion of diatoms by the main grazer, $H$. ulvae, can be estimated to be 37 times more, based on a mean $\mathrm{H}$. ulvae biomass of $4000 \mathrm{mg} \cdot \mathrm{m}^{-2}$ (Lebreton, 2009) and an ingestion rate of 0.04 $\mathrm{mg} \mathrm{C}_{\text {food }}$ source. $\mathrm{mg} \mathrm{C}_{\text {consumer }}{ }^{-1} \cdot \mathrm{m}^{-2} \cdot \mathrm{d}^{-1}$ (Baird et al., 2007). On the contrary,

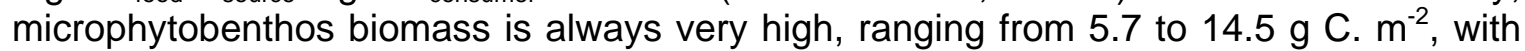
values close to the biomass of Zostera leaves (Lebreton et al., 2009) and its production, even it is less available to grazers, appears to be a much more important resources for invertebrates than epiphytes.

The importance of microphytobenthos for grazers was already noticed in the Gulf of Mexico (Moncreiff and Sullivan, 2001), in the Baltic (Jaschinski et al., 2008) and the Mediterranean Seas (Dauby, 1995; Lepoint et al., 2000), but only as a complementary source to epiphytic diatoms. On the contrary, Kharlamenko et al. (2001) consider that the main diet of gastropod grazers in Novgorodskaya Bay is based on epiphytes; however, the microphytobenthos was not quantified in their study and it is thus not possible to conclude on the actual importance of this food source. Very few studies have really quantified the actual contributions of different sources, probably because the microphytobenthos is difficult to isolate. 
In the intertidal seagrass bed studied here, the importance of the microphytobenthos compared to epiphytes was more easily highlighted, due to the very low biomass - and potential production - of epiphytes. Microphytobenthos appears to be the main trophic resource for four consumers having different feeding types (grazers, deposit feeders, suspension-deposit feeders) and accounts for a large portion of the diet in the two suspension feeders. The role of microphytobenthos is therefore of paramount importance in this seagrass bed food web: the predominance of benthic microalgae in macrofaunal diets is probably due to their higher nutritional quality and assimilation rates compared to those of vascular plants (Cebrián, 1999) and to their constant biomass throughout the year (Auby and Labourg, 1996; Lebreton et al., 2009).

\section{Conclusion}

As the six consumer species analyzed dominate the macrofauna (representing more than $90 \%$ of the total biomass), the present study illustrates the general trophodynamics between producers and macrofaunal consumers in this intertidal seagrass bed. We showed that pelagic, epiphytic or microphytobenthic diatoms represent the main part of these consumers' diets. Among these food sources, microphytobenthos appears to be the main trophic resource in consumer diets, which could be explained by its high biomass, its constant availability and its high nutritional quality. The role of microphytobenthos nevertheless remains poorly understood in most seagrass beds and may be largely underestimated, even when seagrass leaves have a large epiphyte load, and it deserves a better consideration in future studies of seagrass trophic webs.

\section{Acknowledgements}

This study is part of B. Lebreton's Ph.D. thesis, that was supported by the French Ministry for Higher Education and Research, and participated to the MARBEF FoodWebio project. Fundings were also obtained through the research programs ' $\mathrm{ACl}$ Ecologie Quantitative' and 'Programme National d'Environnement Côtier', and the Poitou-Charentes Region programme CPER 2007-2013. The authors thank M. Bréret, P. Pineau, T. Guyot, J. Pigeot, D. Vilday for their help during field work and G. Colli, P.E. Buffet for their help in sample preparations, as well as the staff at the 'Réserve naturelle nationale de Moëze-Oléron', and the two helpful anonymous reviewers.

\section{References}

Abraham, W.-R., Hesse, C., Pelz, O., 1998. Ratios of carbon isotopes in microbial lipids as an indicator of substrate usage. Applied and Environmental Microbiology 64, 42024209.

Asmus, H., Asmus, R., 1985. The importance of grazing food chain for energy flow and production in three intertidal sand bottom communities of the northern Wadden Sea. Helgoländer Meeresuntersuchungen 39, 273-301.

Auby, I., Labourg, P.-J., 1996. Seasonal dynamics of Zostera noltii Hornem. in Bay of Arcachon (France). Journal of Sea Research 35, 269-277.

Baird, D., Asmus, H., Asmus, R., 2007. Trophic dynamics of eight intertidal communities of the Sylt-Rømø Bight ecosystem, northern Wadden Sea. Marine Ecology Progress Series 351, 25-41.

Bannon, C. D., Craske, J. D., Hilliker, A. E., 1986. Analysis of fatty acid methyl esters with high accuracy and reliability. $\mathrm{V}$. Validation of theoretical relative response factors of 
unsaturated esters in the flame ionization detector. Journal of the American Oil Chemists' Society 63, 105-110.

Benner, R., Fogel, M. L., Sprague, E. K., Hodson, R. E., 1987. Depletion of ${ }^{13} \mathrm{C}$ in lignin and its implication for stable carbon isotope studies. Nature 329, 708-710.

Bergé, J.-P., Gouygou, J.-P., Dubacq, J.-P., Durand, P., 1995. Reassessment of lipid composition of the diatom, Skeletonema costatum. Phytochemistry 39, 1017-1021.

Borowitzka, M. A., Lavery, P. S., van Keulen, M., 2006. Epiphytes of seagrasses. In: Larkum, A. W. D., Orth, R. J., Duarte, C. M. (Eds.), Seagrasses: biology, ecology and conservation. Springer, Dordrecht, pp. 441-461.

Boschker, H. T. S., Wielemaker, A., Schaub, B. E. M., Holmer, M., 2000. Limited coupling of macrophyte production and bacterial carbon cycling in the sediments of Zostera spp. meadows. Marine Ecology Progress Series 203, 181-189.

Canuel, E. A., Martens, C. S., 1996. Reactivity of recently deposited organic matter: degradation of lipid compounds near the sediment-water interface. Geochimica et Cosmochimica Acta 60, 1793-1806.

Carlier, A., Riera, P., Amouroux, J.-M., Bodiou, J.-Y., Desmalades, M., Grémare, A., 2009. Spatial heterogeneity in the food web of a heavily modified Mediterranean coastal lagoon: stable isotope evidence. Aquatic Biology 5, 167-170.

Cattaneo, A., Méthot, G., Pinel-Alloul, B., Niyonsenga, T., Lapierre, L., 1995. Epiphyte size and taxonomy as biological indicators of ecological and toxicological factors in Lake Saint-François (Québec). Environmental Pollution 87, 357-372.

Cebrián, J., 1999. Patterns in the fate of production in plant communities. The American Naturalist 154, 449-468.

Choy, E. J., An, S., Kang, C.-K., 2008. Pathways of organic matter through food webs of diverse habitats in the regulated Nakdong River estuary (Korea). Estuarine, Coastal and Shelf Science 78, 215-226.

Christie, W. W., 1984. Extraction and hydrolysis of lipids and some reactions of their fatty acid components. In: Zweig, G., Sherma, J. (Eds.), Handbook of chromatography, Lipids. CRC Press, Boca Raton, pp. 33-46.

Christie, W. W., 1988. Equivalent chain-lengths of methyl ester derivatives of fatty acids on gas chromatography. A reappraisal. Journal of Chromatography 447, 305-314.

Coleman, V. L., Burkholder, J. M., 1995. Response of microalgal epiphyte communities to nitrate enrichment in an eelgrass (Zostera marina) meadow. Journal of Phycology 31, 36-43.

Copeman, L. A., Parrish, C. C., Gregory, R. S., Jamieson, R. E., Wells, J., Whiticar, M. J., 2009. Fatty acid biomarkers in coldwater eelgrass meadows: elevated terrestrial input to the food web of age-0 Atlantic cod Gadus morhua. Marine Ecology Progress Series 386, 237-251.

Daehnick, A. E., Sullivan, M. J., Moncreiff, C. A., 1992. Primary production of the sand microflora in seagrass beds of Mississipi sound. Botanica Marina 35, 131-139.

Dauby, P. A., 1995. A $\delta^{13} \mathrm{C}$ study of the feeding habits in four mediterranean Leptomysis species (Crustacea: Mysidacea). Pubblicazioni della Stazione Zoologica di Napoli I. Marine Ecology 16, 93-102.

Dechambenoy, C. L., Pontier, F., Sirou, F., Vouvé, J., 1977. Apport de la thermographie infrarouge aéroportée à la connaissance de la dynamique superficielle des estuaires (système Charente-Seudre-Anse de l'Aiguillon). Comptes Rendus de l'Académie des Sciences. Paris 284, 1269-1272.

Dijkstra, P., LaViolette, C. M., Coyle, J. S., Doucett, R. R., Schwartz, E., Hart, S. C., Hungate, B. A., 2008 . ${ }^{15} \mathrm{~N}$ enrichment as an integrator of the effects of $\mathrm{C}$ and $\mathrm{N}$ on microbial metabolism and ecosystem function. Ecology Letters 11, 389-397.

Duarte, C. M., 1989. Temporal biomass variability and production/biomass relationships of seagrass communities. Marine Ecology Progress Series 51, 269-276.

Duarte, C. M., Chiscano, C. L., 1999. Seagrass biomass and production: a reassessment. Aquatic Botany 65, 159-174. 
Dunstan, G. A., Volkman, J. K., Barrett, S. M., Leroi, J.-M., Jeffrey, S. W., 1994. Essential polyunsaturated fatty acids from 14 species of diatom (Bacillariophyceae). Phytochemistry 35, 155-161.

Fenchel, T., 1988. Marine plankton food chains. Annual Review of Ecology and Systematics 19, 19-38.

Folch, J., Lees, M., Sloane Stanley, G. H., 1957. A simple method for the isolation and purification of total lipides from animal tissues. The Journal of Biological Chemistry 226, 497-509.

Fry, B., Macko, S. A., Zieman, J. C., 1987. Review of stable isotopic investigations of food webs in seagrass meadows. Proceedings of the symposium on subtropical-tropical seagrasses of the southeastern United States. Florida Marine Research Publications, Gainesville, pp. 117-138.

Fry, B., 2006. Stable isotope ecology. Springer, New-York, 308 pp.

Galois, R., Richard, P., Fricourt, B., 1996. Seasonal variations in suspended particulate matter in the Marennes-Oléron Bay, France, using lipids as biomarkers. Estuarine, Coastal and Shelf Science 43, 335-357.

Green, E. P., Short, F. T., 2003. World atlas of seagrasses. University of California Press, Berkeley, $310 \mathrm{p}$.

Grossmann, S., Reichardt, W., 1991. Impact of Arenicola marina on bacteria in intertidal sediments. Marine Ecology Progress Series 77, 85-93.

Guarini, J.-M., Blanchard, G. F., Bacher, C., Gros, P., Riera, P., Richard, P., Gouleau, D., Galois, R., Prou, J., Sauriau, P.-G., 1998. Dynamics of spatial patterns of microphytobenthic biomass: inferences from a geostatistical analysis of two comprehensive surveys in Marennes-Oléron Bay (France). Marine Ecology Progress Series 166, 131-141.

Guarini, J.-M., Blanchard, G. F., Gros, P., 2000. Quantification of the microphytobenthic primary production in European intertidal mudflats - a modelling approach. Continental Shelf Research 20, 1771-1788.

Guillaumont, B., 1991. Utilisation de l'imagerie satellitaire pour des comparaisons spatiales et temporelles en zone intertidale. Estuaries and coasts: spatial and temporal intercomparisons. ECSA19 Symposium. Olsen \& Olsen, Fredensborg, pp. 63-68.

Harrison, P. G., 1982. Control of microbial growth and of amphipod grazing by watersoluble compounds from leaves of Zostera marina. Marine Biology 67, 225-230.

Héral, M., Deslous-Paoli, J.-M., Prou, J., Razet, D., 1987. Relations entre la nourriture disponible et la production de mollusques en milieu estuarien : variabilité temporelle de la colonne d'eau. Haliotis 16, 149-158.

Herlory, O., Richard, P., Blanchard, G. F., 2007. Methodology of light response curves: application of chlorophyll fluorescence to microphytobenthic biofilms. Marine Biology 153, 91-101.

Hootsmans, M. J. M., Vermaat, J. E., Beijer, J. A. J., 1993. Periphyton density and shading in relation to tidal depth and fiddler crab activity in intertidal seagrass beds of the Banc d'Arguin (Mauritania). Hydrobiologia 258, 73-80.

Jacobs, R. P. W. M., Huisman, W. H. T., 1982. Macrobenthos of some Zostera beds in the vicinity of Roscoff (France) with special reference to relations with community structure and environmental factors. Proceedings Koninglijke Nederlandse Akademie van Wedenschappen Series C-Biological and Medical Sciences 85, 335-356.

Jaschinski, S., Brepohl, D. C., Sommer, U., 2008. Carbon sources and trophic structure in an eelgrass Zostera marina bed, based on stable isotope and fatty acid analyses. Marine Ecology Progress Series 358, 103-114.

Kang, C. K., Sauriau, P.-G., Richard, P., Blanchard, G. F., 1999. Food sources of the infaunal suspension-feeding bivalve Cerastoderma edule in a muddy sandflat of Marennes-Oléron Bay, as determined by analyses of carbon and nitrogen stable isotopes. Marine Ecology Progress Series 187, 147-158.

Kharlamenko, V. I., Kiyashko, S. I., Imbs, A. B., Vyshkvartzev, D. I., 2001. Identification of food sources of invertebrates from the seagrass Zostera marina community using 
carbon and sulfur stable isotope ratio and fatty acid analyses. Marine Ecology Progress Series 220, 103-117.

Kharlamenko, V. I., Kiyashko, S. I., Rodkina, S. A., Imbs, A. B., 2008. Determination of food sources of marine invertebrates from a subtidal sand community using analyses of fatty acids and stable isotopes. Russian Journal of Marine Biology 34, 101-109.

Khotimchenko, S. V., 1993. Fatty acids and polar lipids of seagrasses from the sea of Japan. Phytochemistry 33, 369-372.

Kitting, C. L., Fry, B., Morgan, M. D., 1984. Detection of inconspicuous epiphytic algae supporting food webs in seagrass meadows. Oecologia 62, 145-149.

Koch, E. W., Ackerman, J. D., Verduin, J., van Keulen, M., 2006. Fluid dynamics in seagrass ecology - from molecules to ecosystems. In: Larkum, A. W. D., Orth, R. J., Duarte, C. M. (Eds.), Seagrasses: biology, ecology and conservation. Springer, Dordrecht, pp. 193-225.

Lebreton, B., 2009. Analyse de la structure et du fonctionnement du réseau trophique d'un herbier par approche multi-traceurs : traçage isotopique naturel et profils acides gras. Cas de l'herbier intertidal de Zostera noltii du bassin de Marennes-Oléron, France. Ph.D. thesis, La Rochelle Univ., France, unpublished.

Lebreton, B., Richard, P., Radenac, G., Bordes, M., Bréret, M., Arnaud, C., Mornet, F., Blanchard, G. F., 2009. Are epiphytes a significant component of intertidal Zostera noltii beds? Aquatic Botany 91, 82-90.

Leduc, D., Probert, P. K., Frew, R. D., Hurd, C. L., 2006. Macroinvertebrate diet in intertidal seagrass and sandflat communities: a study using $C, N$, and $S$ stable isotopes. New Zealand Journal of Marine and Freshwater Research 40, 615-629.

Lepoint, G., Nyssen, F., Gobert, S., Dauby, P., Bouquegneau, J.-M., 2000. Relative impact of a seagrass bed and its adjacent epilithic algal community in consumer diets. Marine Biology 136, 513-518.

MacIntyre, H. L., Geider, R. J., Miller, D. C., 1996. Microphytobenthos: The ecological role of the "secret garden" of unvegetated, shallow-water marine habitats. I. Distribution, abundance and primary production. Estuaries 19, 186-201.

Malet, N., Sauriau, P.-G., Ryckaert, M., Malestroit, P., Guillou, G., 2008. Dynamics and sources of suspended particulate organic matter in the Marennes-Oléron oyster farming bay: Insights from stable isotopes and microalgae ecology. Estuarine, Coastal and Shelf Science 78, 576-586.

Mateo, M. A., Cebrián, J., Dunton, K., Mutchler, T., 2006. Carbon flux in seagrass ecosystems. In: Larkum, A. W. D., Orth, R. J., Duarte, C. M. (Eds.), Seagrasses: biology, ecology and conservation. Springer, Dordrecht, pp. 159-192.

Meziane, T., Tsuchiya, M., 2000. Fatty acids as tracers of organic matter in the sediment and food web of a mangrove/intertidal flat ecosystem, Okinawa, Japan. Marine Ecology Progress Series 200, 49-57.

Moncreiff, C. A., Sullivan, M. J., 2001. Trophic importance of epiphytic algae in subtropical seagrass beds: evidence from multiple stable isotope analyses. Marine Ecology Progress Series 215, 93-106.

Moncreiff, C. A., Sullivan, M. J., Daehnick, A. E., 1992. Primary production dynamics in seagrass beds of Mississippi Sound: the contributions of seagrass, epiphytic algae, sand microflora, and phytoplankton. Marine Ecology Progress Series 87, 161-171.

Moorthi, S., Berninger, U.-G., 2006. Mixotrophic nanoflagellates in coastal sediments in the western Baltic Sea. Aquatic Microbial Ecology 45, 79-87.

Nichols, P. D., Klumpp, D. W., Johns, R. B., 1982. Lipid components of the seagrasses Posidonia australis and Heterozostera tasmanica as indicators of carbon source. Phytochemistry 21, 1613-1621.

Nichols, P. D., Jones, G. J., de Leeuw., J. W., Johns, R. B., 1984. The fatty acid and sterol composition of two marine dinoflagellates. Phytochemistry 23, 1043-1047.

Nyssen, F., Brey, T., Dauby, P., Graeve, M., 2005. Trophic position of Antarctic amphipods-enhanced analysis by a 2-dimensional biomarker assay. Marine Ecology Progress Series 300, 135-145. 
Pascal, P.-Y., Dupuy, C., Richard, P., Mallet, C., Armynot du Chatelet, E., Niquil, N., 2009. Seasonal variation in consumption of benthic bacteria by meio- and macrofauna in an intertidal mudflat. Limnology and Oceanography 54, 1048-1059.

Philippart, C. J. M., 1995. Effect of periphyton grazing by Hydrobia ulvae on the growth of Zostera noltii on a tidal flat in the Dutch Wadden Sea. Marine Biology 122, 431-437.

Rajendran, N., Suwa, Y., Urushigawa, Y., 1993. Distribution of phospholipid ester-linked fatty acid biomarkers for bacteria in the sediment of Ise Bay, Japan. Marine Chemistry 42, 39-56.

Ramos, C. S., Parrish, C. C., Quibuyen, T. A. O., Abrajano, T. A., 2003. Molecular and carbon isotopic variations in lipids in rapidly settling particles during a spring phytoplankton bloom. Organic Geochemistry 34, 195-207.

Raniello, R., Iannicelli, M. M., Nappo, M., Avila, C., Zupo, V., 2007. Production of Cocconeis neothumensis (Bacillariophyceae) biomass in batch cultures and bioreactors for biotechnological applications: light and nutrient requirements. Journal of Applied Phycology 19, 383-391.

Renaud, S. M., Thinh, L.-V., Parry, D. L., 1999. The gross chemical composition and fatty acid composition of 18 species of tropical Australian microalgae for possible use in mariculture. Aquaculture 170, 147-159.

Riera, P., Richard, P., 1996. Isotopic determination of food sources of Crassostrea gigas along a trophic gradient in the estuarine bay of Marennes-Oléron. Estuarine, Coastal and Shelf Science 42, 347-360.

Riera, P., Richard, P., 1997. Temporal variation of $\delta^{13} \mathrm{C}$ in particulate organic matter and oyster Crassostrea gigas in Marennes-Oléron Bay (France): effect of freshwater inflow. Marine Ecology Progress Series 147, 105-115.

Round, F. E., Crawford, R. M., Mann, D. G., 1990. The Diatoms: biology and morphology of the genera. Cambridge University Press, Cambridge, $747 \mathrm{p}$.

Sargent, J. R., Whittle, K. J., 1981. Lipids and hydrocarbons in the marine food web. In: Longhurst, A. R. (Ed.), Analysis of marine ecosystems. Academic Press, London, pp. 491-533.

Sargent, J. R., Parkes, R. J., Mueller-Harvey, I., Henderson, R. J., 1987. Lipid biomarkers in marine ecology. In: Sleigh, M. A. (Ed.), Microbes in the sea. Ellis Horwood Limited, Chichester, pp. 119-138.

Schaal, G., Riera, P., Leroux, C., 2008. Trophic coupling between two adjacent benthic food webs within a man-made intertidal area: A stable isotopes evidence. Estuarine, Coastal and Shelf Science 77, 523-534.

Schanz, A., Polte, P., Asmus, H., 2002. Cascading effects of hydrodynamics on an epiphyte-grazer system in intertidal seagrass beds of the Wadden Sea. Marine Biology 141, 287-297.

Shin, P. K. S., Yip, K. M., Xu, W. Z., Wong, W. H., Cheung, S. G., 2008. Fatty acid as markers to demonstrating trophic relationships among diatoms, rotifers and green-lipped mussels. Journal of Experimental Marine Biology and Ecology 357, 75-84.

Tieszen, L. L., Boutton, T. W., Tesdahl, T. W., Slade, N. A., 1983. Fractionation and turnover of stable carbon isotopes in animal tissues: Implications for $\delta^{13} \mathrm{C}$ analysis of diet. Oecologia 57, 32-37.

Valentine, J. F., Heck Jr., K. L., Kirsch, K. D., Webb, D., 2000. Role of sea urchin Lytechinus variegatus grazing in regulating subtropical turtlegrass Thalassia testudinum meadows in the Florida Keys (USA). Marine Ecology Progress Series 200, 213-228.

Vander Zanden, M. J., Rasmussen, J. B., 2001. Variation in $\delta^{15} \mathrm{~N}$ and $\delta^{13} \mathrm{C}$ trophic fractionation: implications for aquatic food web. Limnology and Oceanography 46, 20612066.

Viso, A.-C., Marty, J.-C., 1993. Fatty acids from 28 marine microalgae. Phytochemistry 34, 1521-1533.

Viso, A.-C., Pesando, D., Bernard, P., Marty, J.-C., 1993. Lipid components of the mediterranean seagrass Posidonia oceanica. Phytochemistry 34, 381-387. 
Volkman, J. K., Johns, R. B., Gillan, F. T., Perry, C. J., 1980. Microbial lipids of an intertidal sediment. I. Fatty acids and hydrocarbons. Geochimica et Cosmochimica Acta 44, 1133-1143.

Volkman, J. K., Jeffrey, S. W., Nichols, P. D., Rogers, G. I., Garland, C. D., 1989. Fatty acid and lipid composition of 10 species of microalgae used in mariculture. Journal of Experimental Marine Biology and Ecology 128, 219-240.

Volkman, J. K., Barrett, S. M., Blackburn, S. I., Mansour, M. P., Sikes, E. L., Gelin, F., 1998. Microalgal biomarkers: A review of recent research developments. Organic Geochemistry 29, 1163-1179.

Volkman, J. K., Revill, A. T., Holdsworth, D. G., Fredericks, D., 2008. Organic matter sources in an enclosed coastal inlet assessed using lipid biomarkers and stable isotopes. Organic Geochemistry 39, 689-710.

Vouvé, F., 2000. Régénération benthique dans les vasières intertidales de MarennesOléron : nature de la matière organique, son impact sur la production et l'incorporation de l'ammonium. Ph.D. thesis, Perpignan Univ., France, unpublished.

Wannigama, G. P., Volkman, J. K., Gillan, F. T., Nichols, P. D., Johns, R. B., 1981. A comparison of lipid components of the fresh and dead leaves and pneumatophores of the mangrove Avicennia marina. Phytochemistry 20, 659-666.

Wear, D. J., Sullivan, M. J., Moore, A. D., Millie, D. F., 1999. Effects of water-column enrichment on the production dynamics of three seagrass species and their epiphytic algae. Marine Ecology Progress Series 179, 201-213. 


\section{Tables}

Table 1. Fatty acids used as markers of food sources in the studied Zostera noltii seagrass bed. References: 1: Sargent and Whittle, 1981; 2: Bergé et al., 1995; 3: Rajendran et al., 1993; 4: Wannigama et al., 1981; 5: Kharlamenko et al., 2001; 6: Meziane and Tsuchiya, 2000; 7: Sargent et al., 1987; 8: Viso et al., 1993; 9: Volkman et al., 1989; 10: Viso and Marty, 1993; 11: Dunstan et al., 1994; 12: Renaud et al., 1999; 13: Volkman et al., 1998; 14: Ramos et al., 2003; 15: Volkman et al., 1980; 16: Galois et al., 1996.

\begin{tabular}{|c|c|c|c|}
\hline \multirow{2}{*}{ Group } & \multicolumn{3}{|c|}{ Fatty acid } \\
\hline & Saturated & Monoenoic & Polyenoic \\
\hline \multirow[t]{13}{*}{ Bacteria } & $13: 0(3,15)$ & $15: 1(n-5) c(3,15)$ & \\
\hline & $15: 0(3,15)$ & $15: 1(n-7) \mathrm{c}(3,15)$ & \\
\hline & $17: 0(7)$ & $17: 1(n-5) c(3,15)$ & \\
\hline & $19: 0(7)$ & $17: 1(n-7) c(3,15)$ & \\
\hline & $23: 0(3,6,15)$ & $17: 1(n-8) \mathrm{c}(3,7,15)$ & \\
\hline & $25: 0(3,15)$ & $18: 1(n-7) \mathrm{c}(7,13)$ & \\
\hline & Iso $14: 0(3,7,15)$ & $19: 1(n-5) c(3,15)$ & \\
\hline & Iso $15: 0(3,7,15)$ & $19: 1(n-7) \mathrm{c}(3,15)$ & \\
\hline & Iso $16: 0(3,7,15)$ & $19: 1(n-8) c(3,15)$ & \\
\hline & Iso $17: 0(3,7,15)$ & $19: 1(n-9) c(3,15)$ & \\
\hline & Iso $19: 0(3,7,15)$ & & \\
\hline & Anteiso $15: 0(3,7,15)$ & & \\
\hline & Anteiso 17:0 $(7,15)$ & & \\
\hline \multirow[t]{6}{*}{ Diatoms } & $14: 0(1,9,10,11,14)$ & $16: 1(n-7) \mathrm{c}(2,9,11,14)$ & $16: 2(n-4)(9,11)$ \\
\hline & $16: 0(1,7,13)$ & & $16: 2(n-7)(9)$ \\
\hline & & & $16: 3(n-4)(2,9,11)$ \\
\hline & & & $16: 4(n-1)(2,9,11,14)$ \\
\hline & & & $18: 2(n-7)(11)$ \\
\hline & & & $20: 5(n-3)(1,10,11,14)$ \\
\hline \multirow[t]{7}{*}{ Flagellates } & & & $16: 2(n-6)(9)$ \\
\hline & & & $16: 3(n-3)(9,10)$ \\
\hline & & & $16: 4(n-3)(9,10,12)$ \\
\hline & & & $18: 4(n-3)(7,9,12,14)$ \\
\hline & & & $18: 5(n-3)(7,9)$ \\
\hline & & & $22: 5(n-3)(16)$ \\
\hline & & & $22: 6(n-3)(1,14)$ \\
\hline \multirow[t]{4}{*}{ Vascular plants } & $22: 0(8)$ & & $18: 2(n-6)(5,6,8)$ \\
\hline & $24: 0(4,8)$ & & $18: 3(n-3)(5,8,10)$ \\
\hline & $26: 0(4,8)$ & & \\
\hline & $28: 0(4,8)$ & & \\
\hline \multirow[t]{3}{*}{ Ubiquitous } & $16: 0(1,7,13)$ & & \\
\hline & $18: 0(1,7,13)$ & & \\
\hline & & $18: 1(n-9) \mathrm{c}(1,7)$ & \\
\hline
\end{tabular}




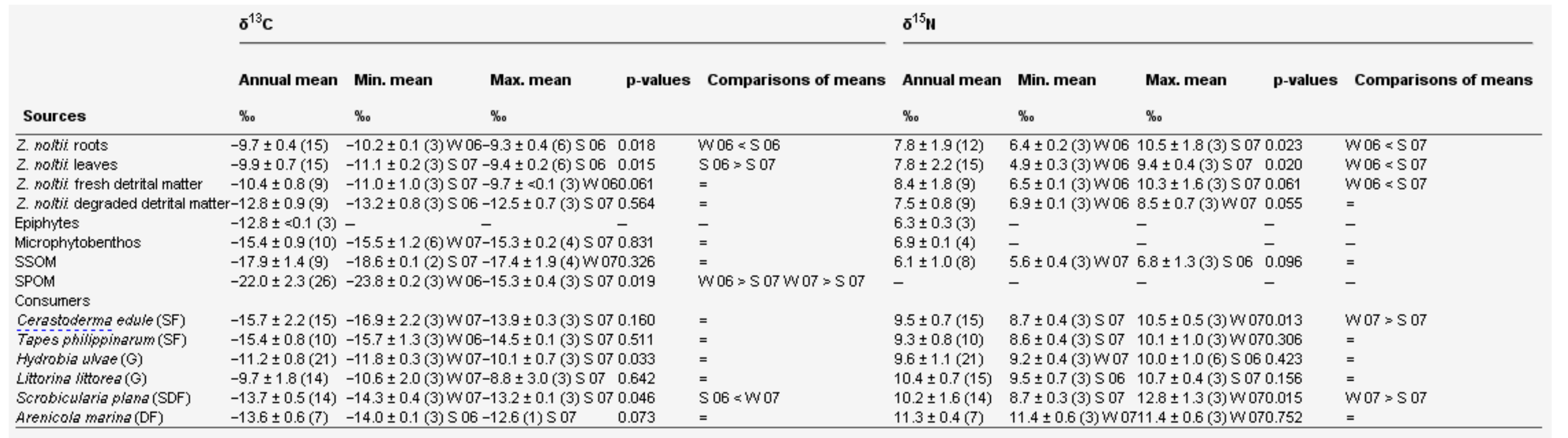

Table 2. Annual mean, minimum and maximum mean of stable isotope ratios $\left(\delta^{13} \mathrm{C}, \delta^{13} \mathrm{~N}\right)$ of food sources and main consumers (\%, mean $\pm \mathrm{SD}$ ), summary of Kruskal-Wallis tests and comparisons of means between sampling seasons (W: winter, S: summer). Replicate numbers are in brackets. Sampling season is stated for minimum and maximum values. Consumer feeding types: DF: Deposit feeder, G: Grazer, SDF: Suspension-deposit feeder, SF: Suspension feeder. 
Table 3 : Seasonal mean, minimum and maximum mean of $\delta^{13} \mathrm{C}$ of SPOM (\%, mean \pm $\mathrm{SD})$ and summary of Kruskal-Wallis tests. Replicate numbers are in brackets.

\begin{tabular}{ccccc}
\hline & \multicolumn{3}{c}{$\delta^{13} \mathrm{C}(\%)$} & p-values \\
\cline { 2 - 4 } & Seasonal mean & Min. mean & Max. mean & \\
\hline Winter 2006 & $-22.5 \pm 1.6(14)$ & $-23.8 \pm 0.2(3)$ & $-21.0 \pm 0.1(3)$ & 0.028 \\
Summer 2006 & $-22.5 \pm 0.7(16)$ & $-22.9 \pm 0.2(3)$ & $-21.4 \pm 0.5(4)$ & 0.062 \\
Winter 2007 & $-23.2 \pm 1.5(5)$ & - & - & -
\end{tabular}

\section{Figures}

Figure 1 : Position of the sampling station in the Zostera noltii seagrass in Marennes Oléron Bay.

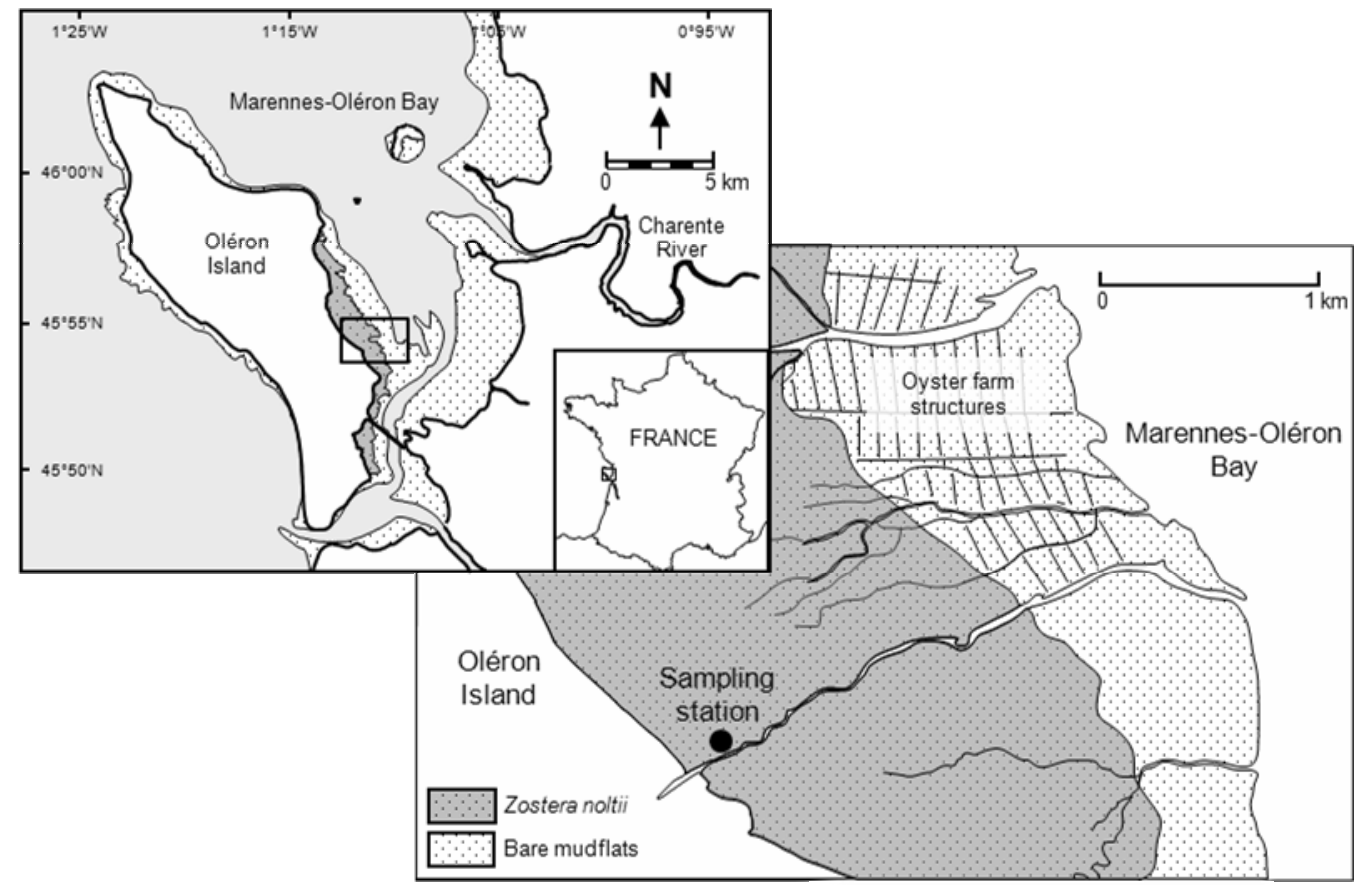


Figure 2: $\delta^{13} \mathrm{C}$ (mean $\pm \mathrm{SD}$ ) of food sources (Fig. 2A) and consumers (Fig. 2B) from winter 2006 to summer 2007 in Marennes-Oléron seagrass bed. SSOM: Surface sediment organic matter; SPOM: Suspended particulate organic matter. In order to distinguish error bars, $\delta^{13} \mathrm{C}$ were temporally shifted ahead 3 days.
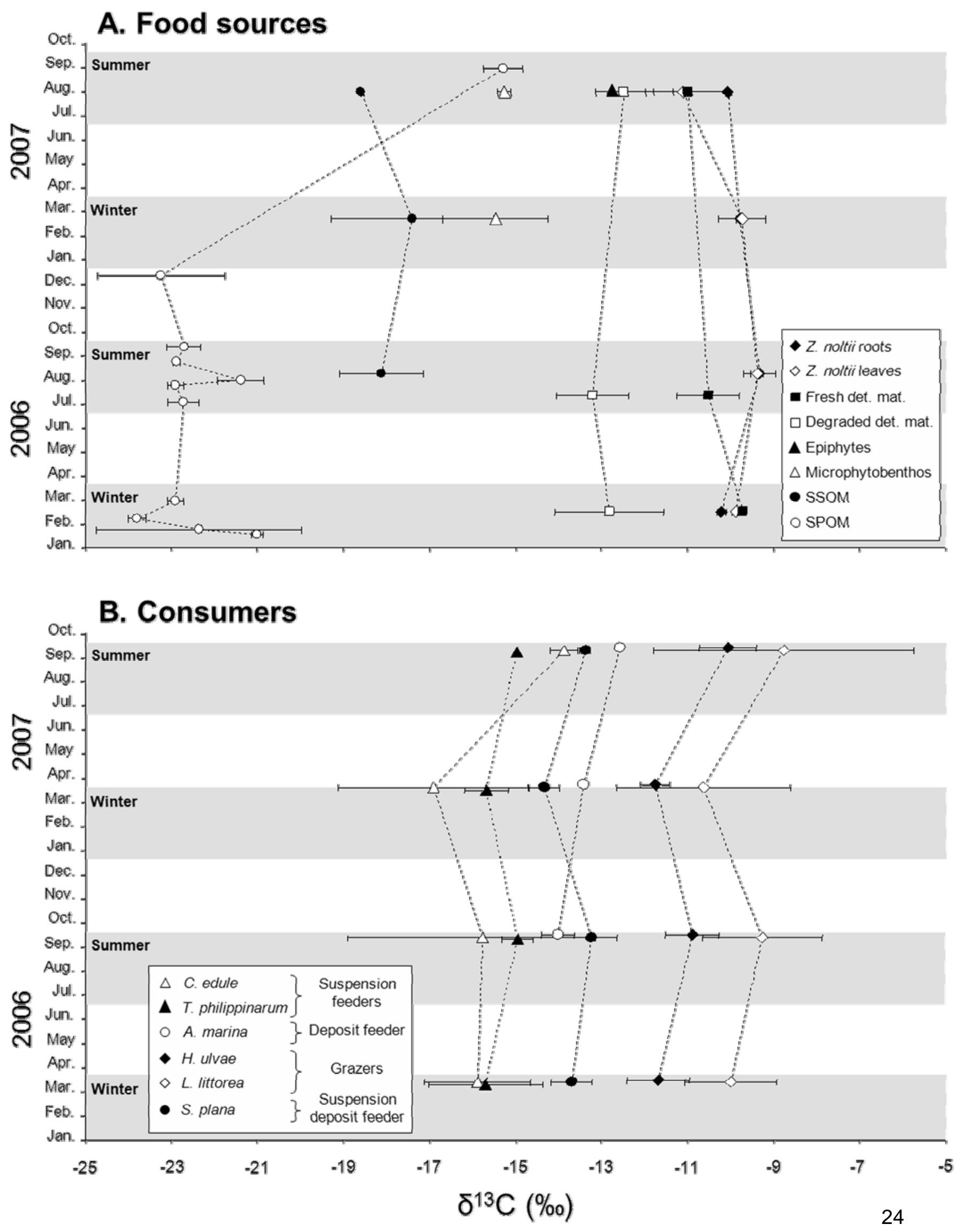
Figure 3 : FA composition (relative percentages) of food sources in winter (Fig. 3A) and summer 2007 (Fig. 3B) in Marennes-Oléron seagrass bed. FAs are grouped according to their marker groups (see Materials and Methods). Only FAs with proportions $\geq 5 \%$ are given and asterisks represent sum of other FAs for each marker group. Hierarchical clustering (Ward's method, Euclidean distance) are showed for each season. p-values from multiscale boostrap resampling are showed under each node and identified clusters $(p<0.050)$ are highlighted with grey rectangles.

\section{Summer 2007}

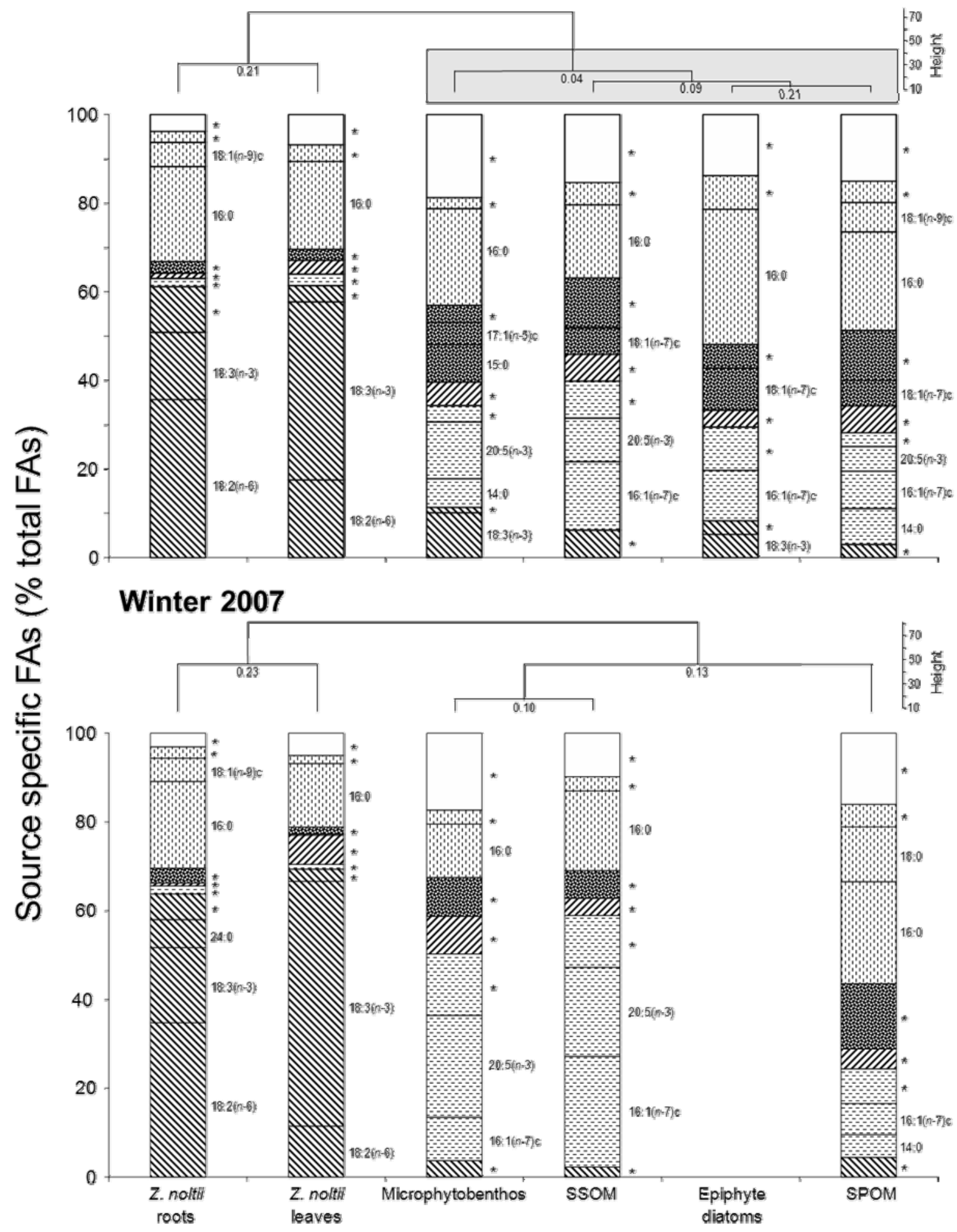

Markers:

MIV vascular plants 
Figure 4 : FA composition (relative percentages) of consumers in winter (Fig. 4A) and summer 2007 (Fig. 4B) in Marennes-Oléron seagrass bed. FAs are grouped according to their marker groups (see Materials and Methods). Only FAs with proportions $\geq 5 \%$ are given and asterisks represent sum of other FAs for each marker group. Hierarchical clustering (Ward's method, Euclidean distance) are showed for each season. p-values from multiscale boostrap resampling are showed under each node and identified clusters $(p<0.050)$ are highlighted with grey rectangles.

\section{Summer 2007}

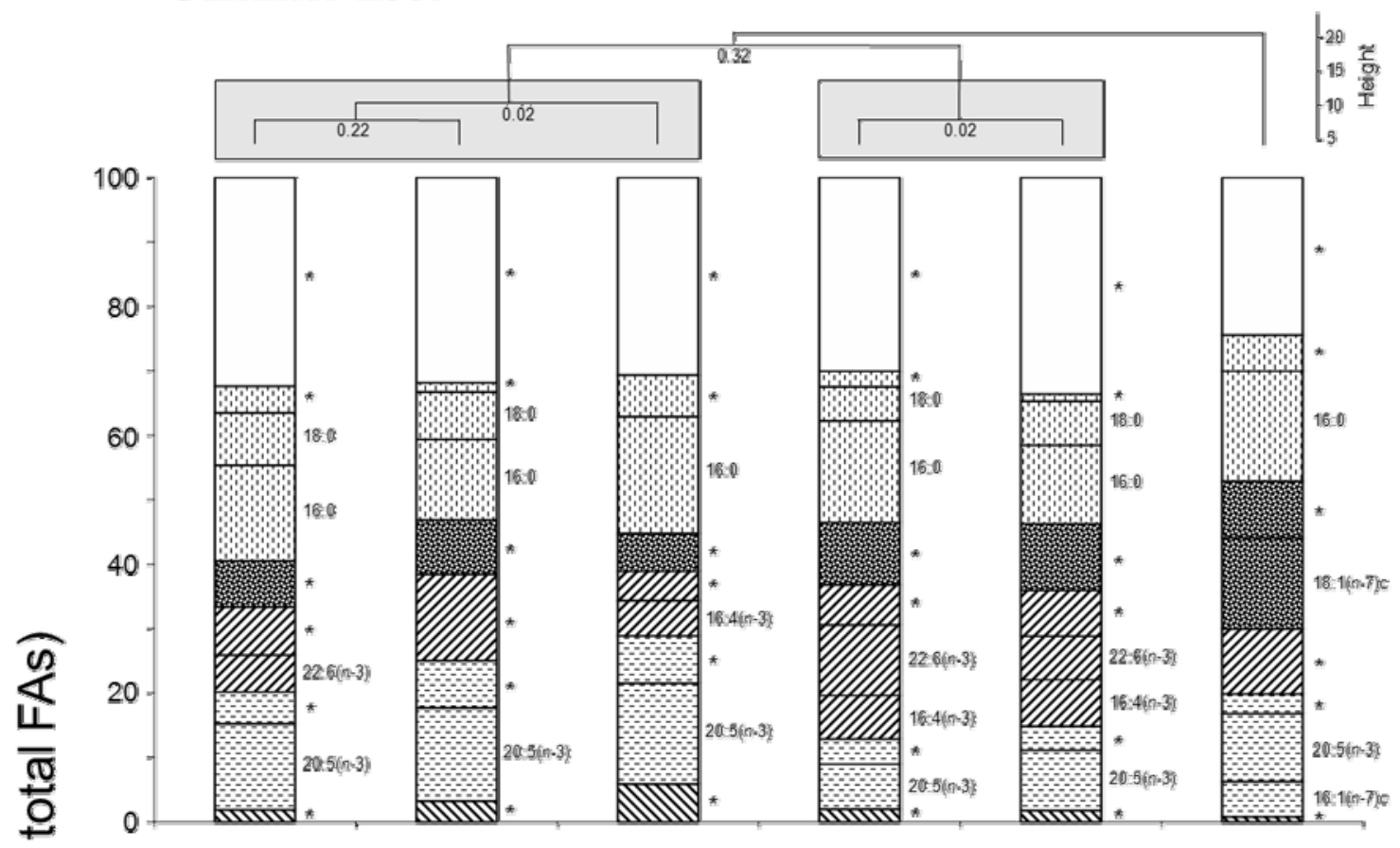

ఏ Winter 2007

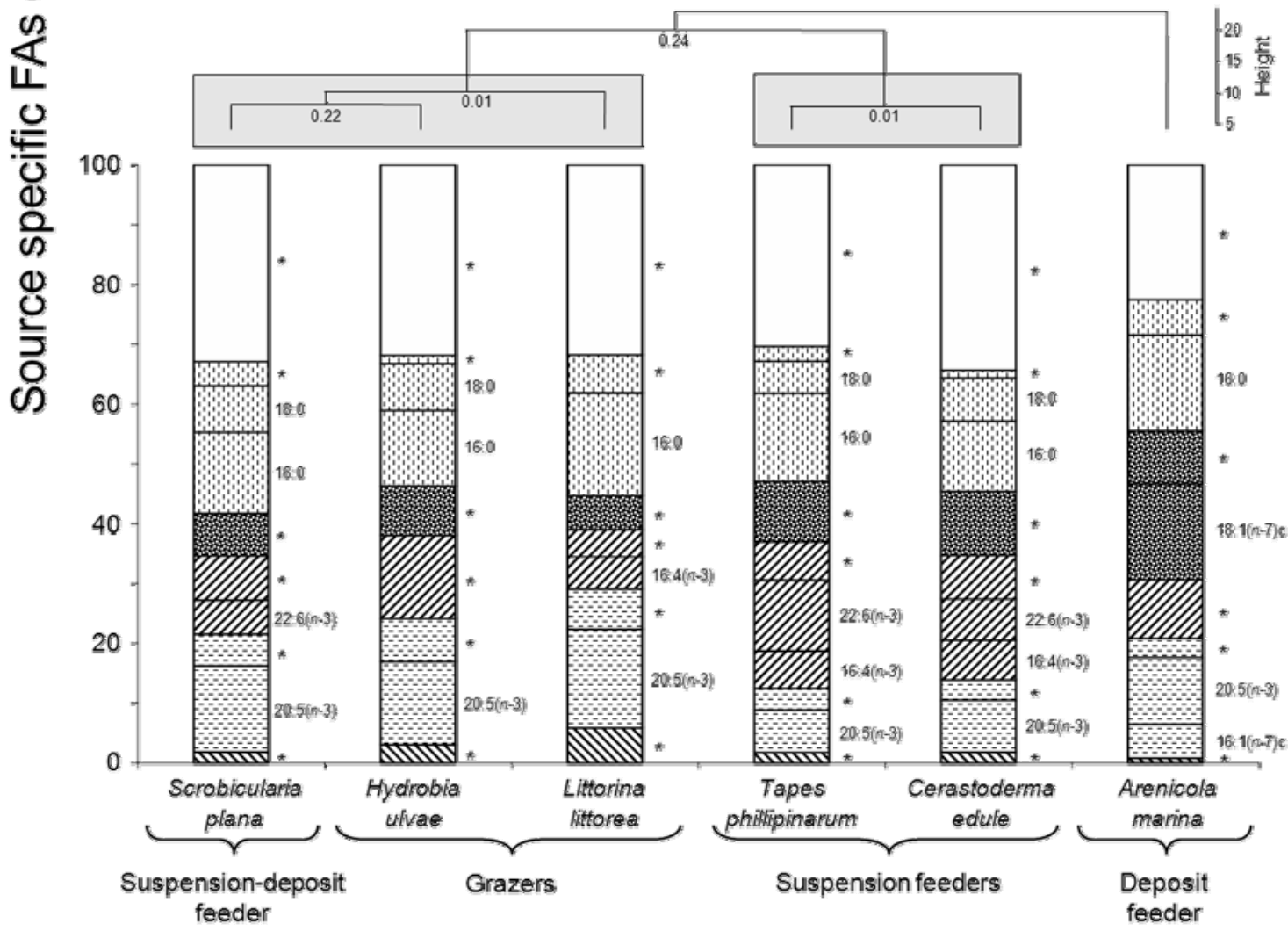

Markers:

MIIV vascular plants 
Figure 5 : Plots of mean $\delta^{13} \mathrm{C}$ (\%) and marker FA composition (relative percentages) of food sources in Marennes-Oléron seagrass bed. FAs were classified according to their marker groups (see Materials and Methods): A: vascular plants, B: diatoms, C: flagellates, D: bacteria. SSOM: Surface sediment organic matter; SPOM: Suspended particulate organic matter.

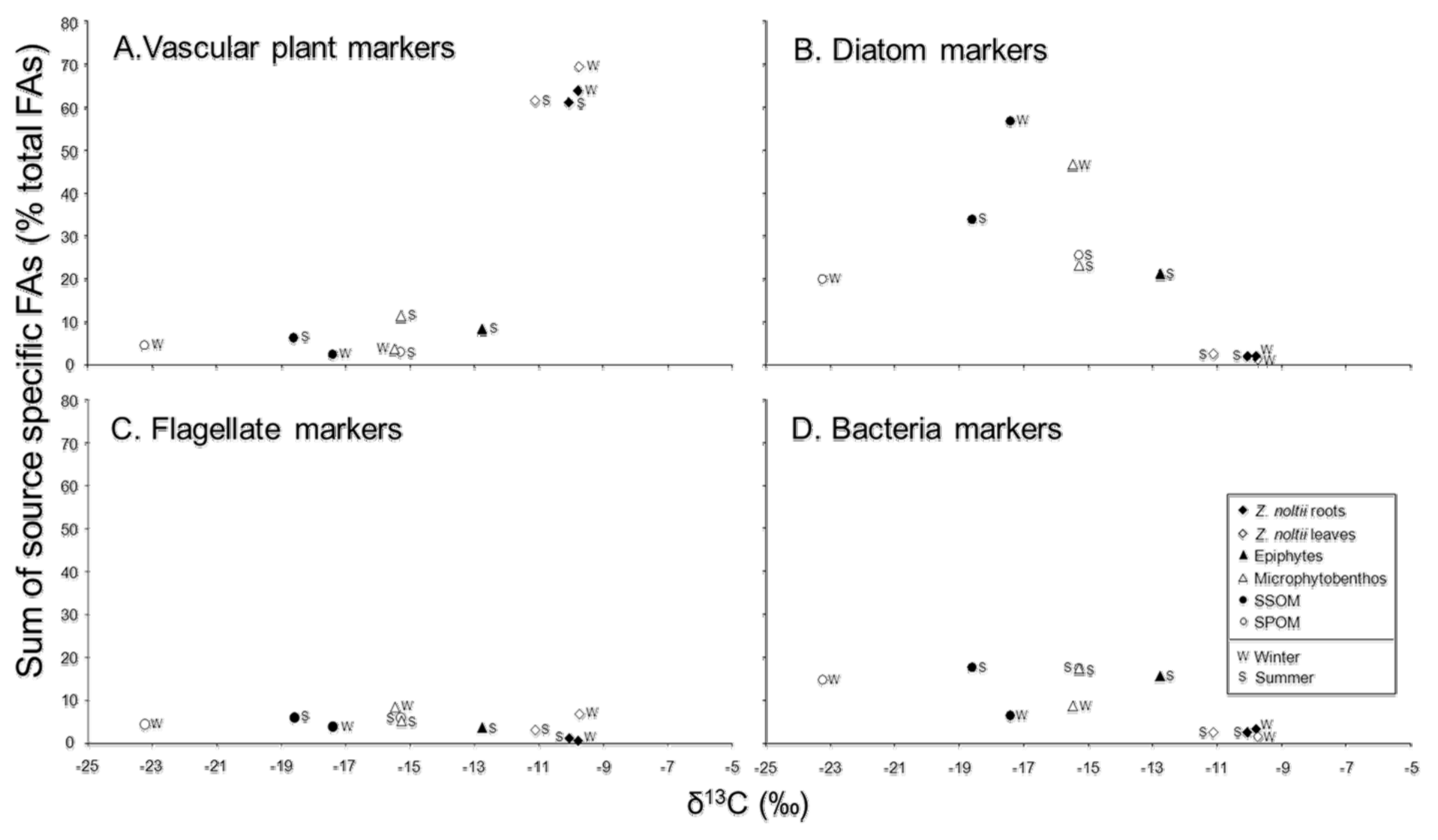


Figure 6 : Plots of mean $\delta^{13} \mathrm{C}(\%)$ and marker FA composition (relative percentages) for consumers in Marennes-Oléron seagrass bed sampled in winter and summer 2007. FAs were classified according to their biomarker properties (see Materials and Methods): A: vascular plants, B: diatoms, C: flagellates, D: bacteria.

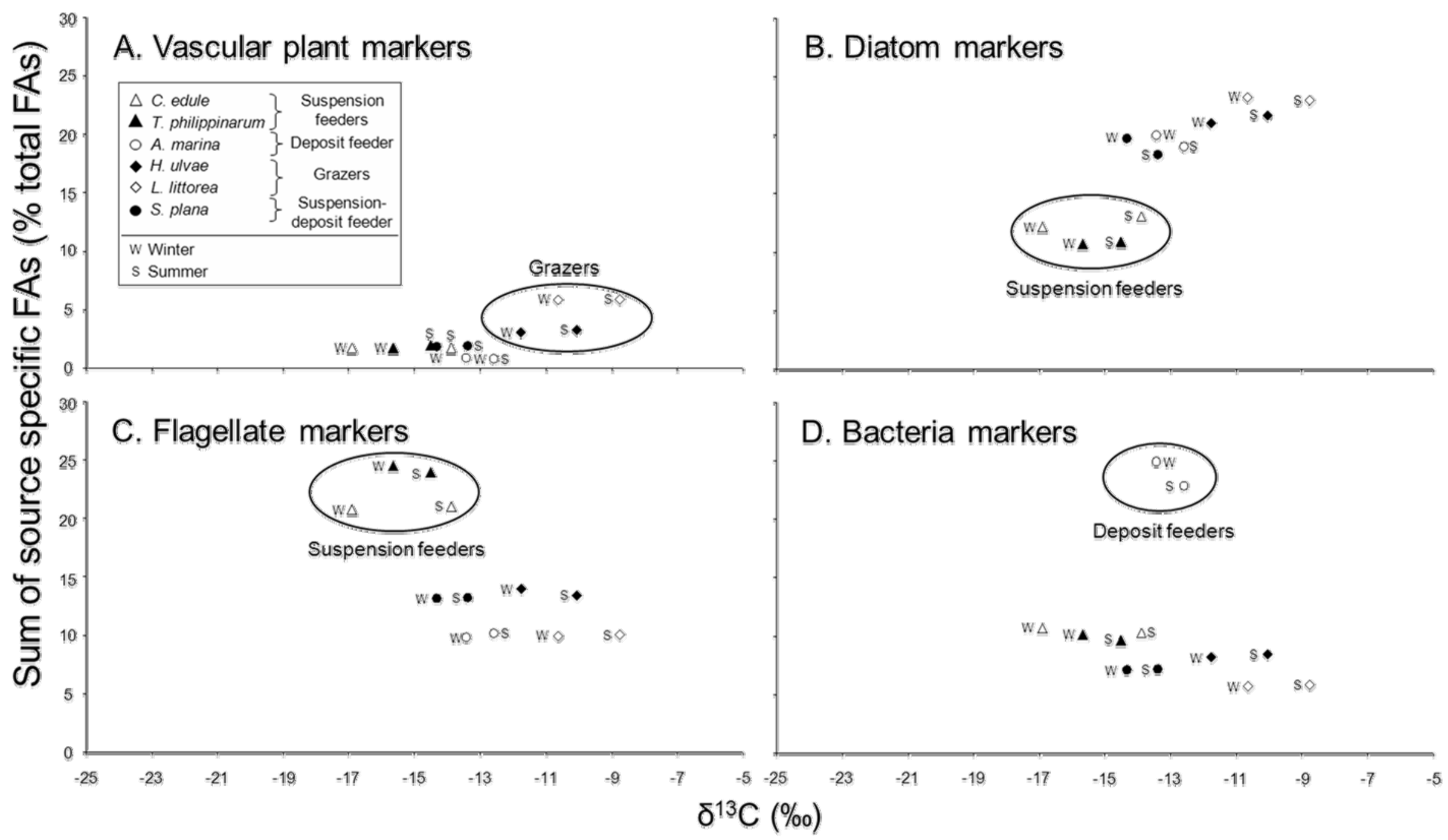

